\title{
Stream Generic Terms as Indicators of Historical Settlement Patterns
}

\section{Jon C. Campbell ${ }^{1}$}

\begin{abstract}
U.S. geographic names may be analyzed with relative ease using data sorting techniques with the Geographic Names Information System. An intensive computer search of the stream names in each state reveals and locates on base maps, using computer-driven plotters, unusual stream generic terms, such as kill, coulee, and cafiada. Tables show the relative frequency and the distribution of toponymic generic terms. The study of selected generic terms in placenames demonstrates some degree of correlation with historical patterns of settlement and provides an instructive, but not always reliable, aid to historical research.
\end{abstract}

\section{$* * * * *$}

\section{Introduction}

Geographic names serve as enduring signposts in the cultural landscape. They reflect historical and cultural motifs, just as barn types, field patterns, and cemetery configurations do. Studies using geographic names as historical evidence usually examine the specific part of the name, such as the surname Kurtz in Kurtz Hill or the word buffalo in Buffalo Creek; but the generic terms in toponyms, the words that indicate the kind of feature named, are no less significant. Generic terms like brook, hollow, sierra, and slough function as distinct grammatical units in geographic names. They are fundamental to the language of place description and wayfinding. While the selection of an apt word as the specific part of a geographic name is subject to few limits, the choice of an appropriate generic term is constrained and directed by the vocabulary of the namer's language or dialect. Because of their original association with definite culture groups, and because generic terms commonly prove to be a durable element in toponyms, the distribution of these terms across the land can give modern observers valuable clues about past cultural settings.

Broad studies of the topic of generic terms in toponyms have previously depended on the manual compilation of terms from maps and gazetteers and so were necessarily restricted to partial analyses of the available data by the immense volume of names to be reviewed and 
tabulated. In a 1956 study, toponymist Meredith Burrill wrote of personally reviewing 15,000 maps and recording placenames, map names, and geographic coordinates on index cards (Burrill 131). Today the existence of the Geographic Names Information System (GNIS) and the automated power of computers make possible the systematic analysis of geographic names on a national scale. Based on a computer-driven review of data in the GNIS, this essay attempts to publicize and illustrate the distribution of the toponymic terms that are found in the names of streams in the United States and to appraise the possible use of this distribution as an indicator of settlement history.

The names of streams were selected as the focus of this study for three reasons. First, more than hills, valleys, or any other class of geographic feature, streams can be easily defined. For this study, the word stream is defined as any natural body of flowing water regardless of size. When a knoll becomes a hill or where a swale changes into a valley may be questioned, but most observers will agree on what traits constitute a stream, although streams sometimes melt into marshes or guts in low areas and in arid regions evaporate into arroyos and washes. Second, streams are more nearly ubiquitous across the landscape than any other class of geographic feature; the existence of stream names in a given area is not as dependent on the topography of that area as are the names of hills, lakes, valleys, or swamps. Some factors that determine the density of stream names are geological conditions, climate, and population density, but except in the most extraordinary circumstances, there are some stream features to be named in any landscape. Third, although American geographic names exhibit an engaging variety of generic terms overall, ${ }^{2}$ fewer than twenty different generic terms make up the vast majority of stream names. The generally uniform spelling of these terms permits an automated search. Also, the word order of stream names that have generic terms from English is predictably specific-generic, as in the name Page Brook. The programmed search employed in this study was designed to expose names that did not fit the anticipated pattern. Routine allowances were made for the generic-specific order of stream names from Romance languages, as in the name Rio Grande.

The emphasis on stream names in this study should not leave the impression that the pattern of a particular generic term in stream names is entirely representative of the pattern of the term in more general geographic nomenclature. To illustrate, in Montana 1,570 valley names, compared to 26 stream names, use coulee as the generic term. Thus the term coulee is much more widespread among all Montana geographic names than the list of stream names alone would indicate. Similarly, the 
terms arroyo or wash may refer to a valley as well as a stream; the term slough may refer to a stream, lake, gut, or swamp.

In many parts of the country there is a local understanding of a hierarchy of stream terms based on stream size. ${ }^{3}$ However, this related topic will not be addressed here. On a national scale the formulation of useful generalizations about the relation of particular stream generic terms to stream size is deterred by the immeasurable factors of the regional importance of this idea, and its actual implementation in stream names, as well as the differing relationships of the various terms.

The National Geographic Names Data Base of the GNIS ${ }^{4}$ is the source of the stream names under consideration. Very nearly all of the stream names found in the GNIS were compiled from federal government topographic maps, principally the large-scale topographic map series published by the U.S. Geological Survey (USGS). The number of stream names in the GNIS changes as the USGS pursues the second phase of geographic names compilation, which includes names from nongovernment publications and historical sources. The total number of stream names in several states increased slightly during the course of this inquiry.

Federally published topographic maps have several deficiencies in toponymy. Government surveyors generally have little specialized training in collecting placenames. The completeness and accuracy of the names may vary with the toponymic interest and cartographic talent of the field surveyors and map editors involved in the production of a map. Misleading placement of names on the map may result in erroneous conclusions about the connotations of generics. Inadequate map symbology can prevent a toponymist from recognizing the distinctions that the inhabitants of an area may use in applying a topographic term. Entering placenames from topographic map sheets into a geographic names data base presents another opportunity for errors in spelling and in classifying placenames into broad feature classes. Despite these shortcomings, the large-scale series of topographic maps published by the USGS render a comprehensive, invaluable collection of placenames of the United States. The names on these maps constitute a sweeping register of the nation's history and culture.

\section{Method}

The method employed in the automated search of the GNIS was uncomplicated. Previous studies of the subject and prior research by the USGS produced a list of twenty-four stream generic terms that were likely to be most prevalent among the country's hydronyms. Each term in this 
list was computer tested by a character-string or text search of all names in the GNIS that are classified as streams. The twenty most common terms were winnowed out for further study. Each term in the select group of twenty appears at least ninety-nine times nationwide as the operative or true generic term in a stream name.

In the interest of consistency, the character-string search tested only whether a stream generic word appeared as a separate word in the name of a stream. Thus, in the search for the term kill, the name Bush Kill Creek would be selected by the computer for more processing and Bushkill Creek with its embedded generic would be discarded. Otherwise, the name Skillet Run would have been erroneously included. The character-string search also tested whether the term is the last word in the name and serves as the operative generic term. The incidence of terms that occur in the interior of stream names, as in South Branch Pronghorn River and Frog Brook Run, was also recorded. Generic terms from Spanish or French (e.g., arroyo or coulee) that might not follow an English word order were individually examined.

After the terms were culled from the GNIS and counted, the resulting data were compiled and constructed into a term-by-term data table (see Appendix), which stresses the percentage of use of generic terms in stream names within a state, not the total number of occurrences. Emphasizing percentages rather than absolute numbers, the results facilitate toponymic comparisons of one geographic area with another. By this method, for example, the great number of streams in Alaska that have the word river as the generic term in their names $(1,284$ occurrences, $15.1 \%$ of all stream generics) does not obscure the fact that the term river is actually more familiar in the hydronymy of Minnesota (425 occurrences, 22.4\%). Similarly, Delaware has fewer streams using the generic prong (22) than Tennessee (37), but in Delaware this term is manifest in 5.1\% of the state's stream names versus $0.4 \%$ in Tennessee.

The data files that had been developed for the data table were then used to produce computer-driven plots that illustrate the distribution of each stream term, except creek and river, throughout the contiguous fortyeight states (see Figs. 1-4). Creek was not plotted because the volume of data for this term made showing individual cases of its occurrence unwieldy even with computer technology. The term river exhibits comparatively little differentiation in its use throughout the nation. Although the plotted distribution of any term is subtly influenced by the wide fluctuation of stream name density across the country, the plots chart geographic patterns of generic term distribution within states and across state boundaries. The distinctive patterns that are revealed in plotting the terms provoke consideration of the basis for their spatial configurations. 


\section{Terms}

The twenty most common stream generic terms in the United States are listed below in descending order of use. The figures in brackets that follow the term indicate, respectively, the percentage of incidence among all stream terms nationwide and the states with the highest percentage of use of that term.

\section{Creek [U.S., 60.9\%; Idaho and Montana, 96.5\%]}

Creek is by far the most common stream generic term in the United States. It occurs most frequently in the stream names of Montana and Idaho. Wyoming, Oregon, South Dakota, Washington, Colorado, and Kansas have the word creek in $90 \%$ or more of their stream names. Creek appears least frequently among the stream names of the New England states; of these, Massachusetts has the highest percentage, with $6.6 \%$. A strong generic term that is itself rarely suppressed into the specific part of a stream name, the term creek has often been added to a stream name with another, possibly older, generic term, for example, Bear Branch Creek and Seco Arroyo Creek. Creek Brook in Essex County, Massachusetts, provides a rare example of creek as the specific.

The standard account of differing applications of the term creek in Great Britain and North America is that early English-speaking explorers of the North American coast bestowed the term on various tidal inlets or arms using the placename terminology customary in England. These creeks retained their designation even after they were found to be tributaries of some length and, consequently, the word creek received a new and different application in the New World (OED; Gritzner 235).

Branch (Fig. 1) [U.S., 16.6\%; Tennessee, 56.8\%]

At its etymological root, the stream term branch is a figurative application suggested by the relation of a branch to a tree. A 1642 citation from the Dictionary of American English on Historical Principles (DAE) refers to "Weston's branch" in Maryland. The use of the term in the sense of a tributary along with a directional specific (as in West Branch North River) is fairly common throughout the country. Using the term in an unequivocal generic sense appears to be an Americanism. The plotted concentration of the term (see Fig. 1) corresponds well to Wilbur Zelinsky's depiction of "The South" culture area in The Cultural Geography of the United States, although the concentration trends somewhat north of Zelinsky's line in the Midwest (118). The term branch as a true generic 
includes a high percentage of the stream names of Tennessee, Kentucky, and Delaware and is quite common throughout the Southeast.

\section{Run (Fig. 1) [U.S., 6.0\%; Pennsylvania, 65.0\%]}

The Oxford English Dictionary (OED) lists a 1581 citation from the legal records of Edinburgh, Scotland, as its earliest reference to the word run as a stream term. In the United States the term is most common among the stream names of Pennsylvania, and run is the generic in about half the stream names of Ohio and West Virginia. Previous studies of toponymic generics by Hans Kurath (40) and Zelinsky ("Some Problems" 326) have pointed out the clear division between the use of run and branch along the Kanawha River in West Virginia. Run is used to refer to smaller streams north of the river; branch is preferred south of the river. The accompanying plots of these terms bear out this observation (see Fig. 1). Kurath equates the distribution of the term run with what he calls the North Midland speech pattern.

\section{Brook (Fig. 1) [U.S., 5.1\%; New Hampshire, 86.3\%]}

The word brook is a longstanding stream term. The earliest reference to its use given by the $O E D$ dates from 888 . The association of this term with the streams of New England is well known, but the term did not travel well with westering New Englanders. New Hampshire has the greatest percentage of streams with the generic brook.

\section{River [U.S., 3.7\%; Minnesota, 22.2\%]}

River is the one stream generic term that definitely denotes size. Hierarchical systems of stream terms based on stream size vary widely across the nation, but the term river is usually reserved for the largest streams. One characteristic exception can be found a few miles west of USGS headquarters near Aldie, Virginia, where the Little River flows into Goose Creek, which in turn flows into the Potomac River. Minnesota has the highest percentage of rivers among its stream names. The term is also relatively more common in the New England states.

The method of data collection in this study understates the importance of the term river in general topographic vocabulary. A long river that may flow through many counties in a state is counted as only one occurrence of the generic term. Nevertheless, as the statistical method is the same in every state, the relative use of the term among states can still be evaluated. 


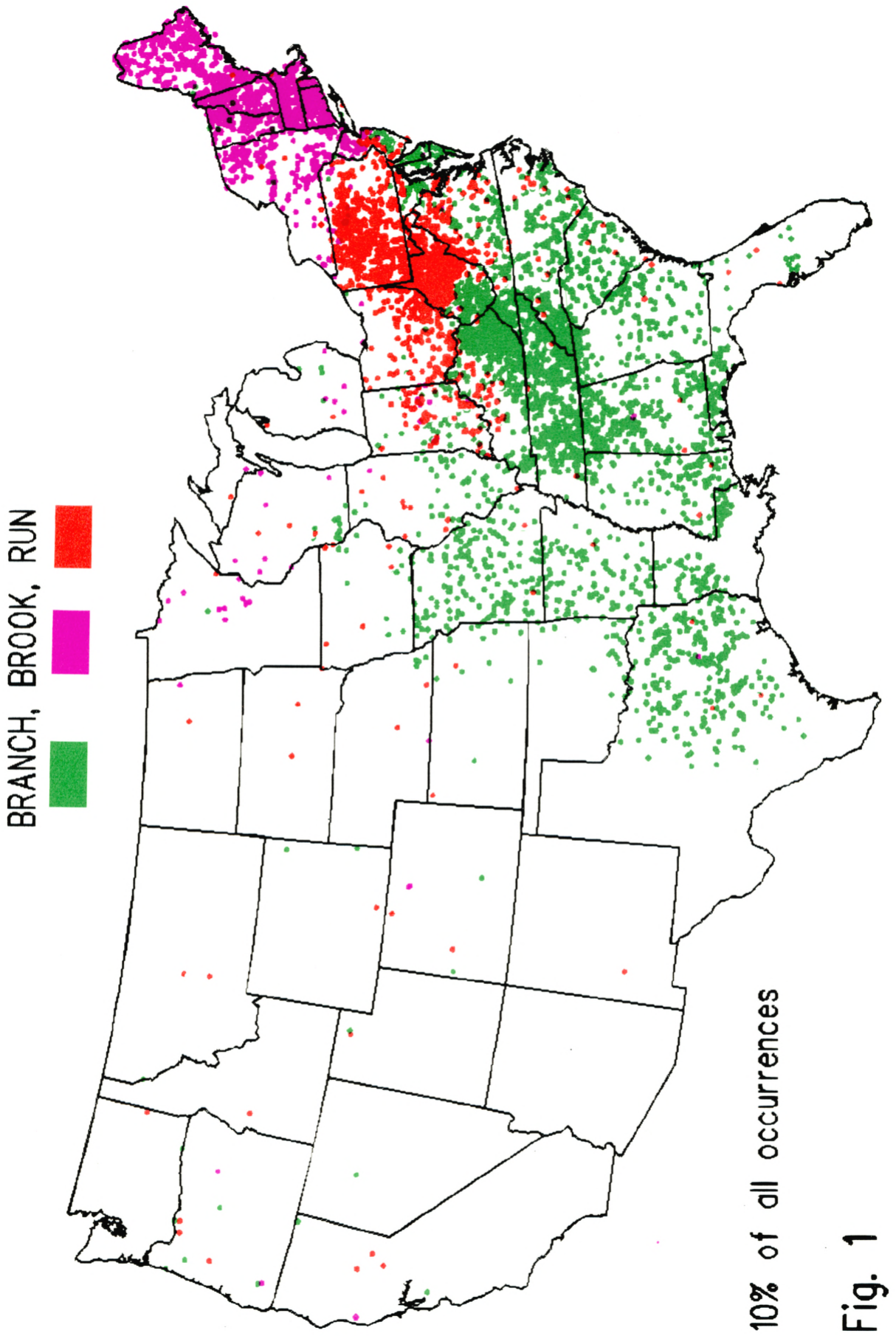




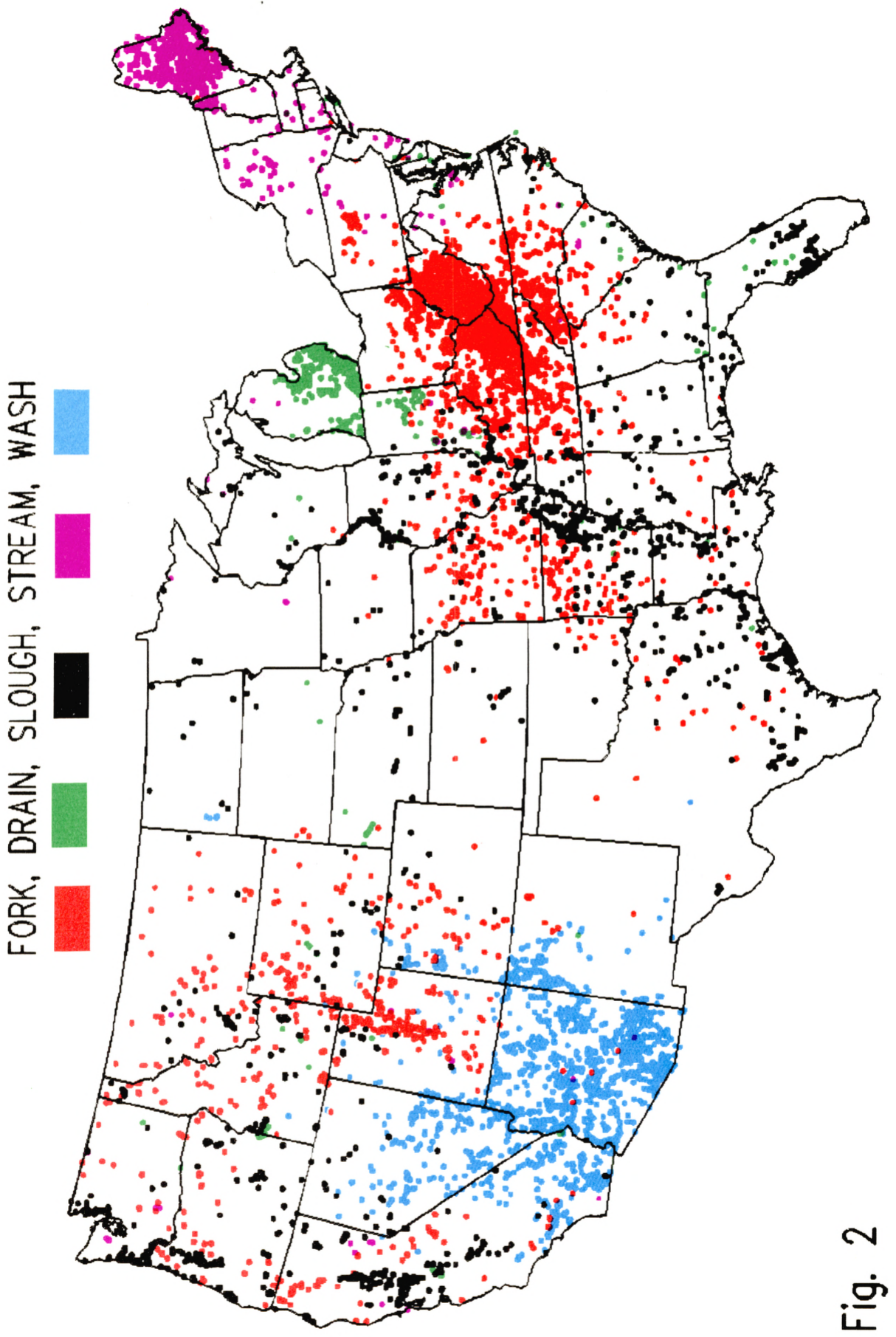


Stream Generic Terms 341

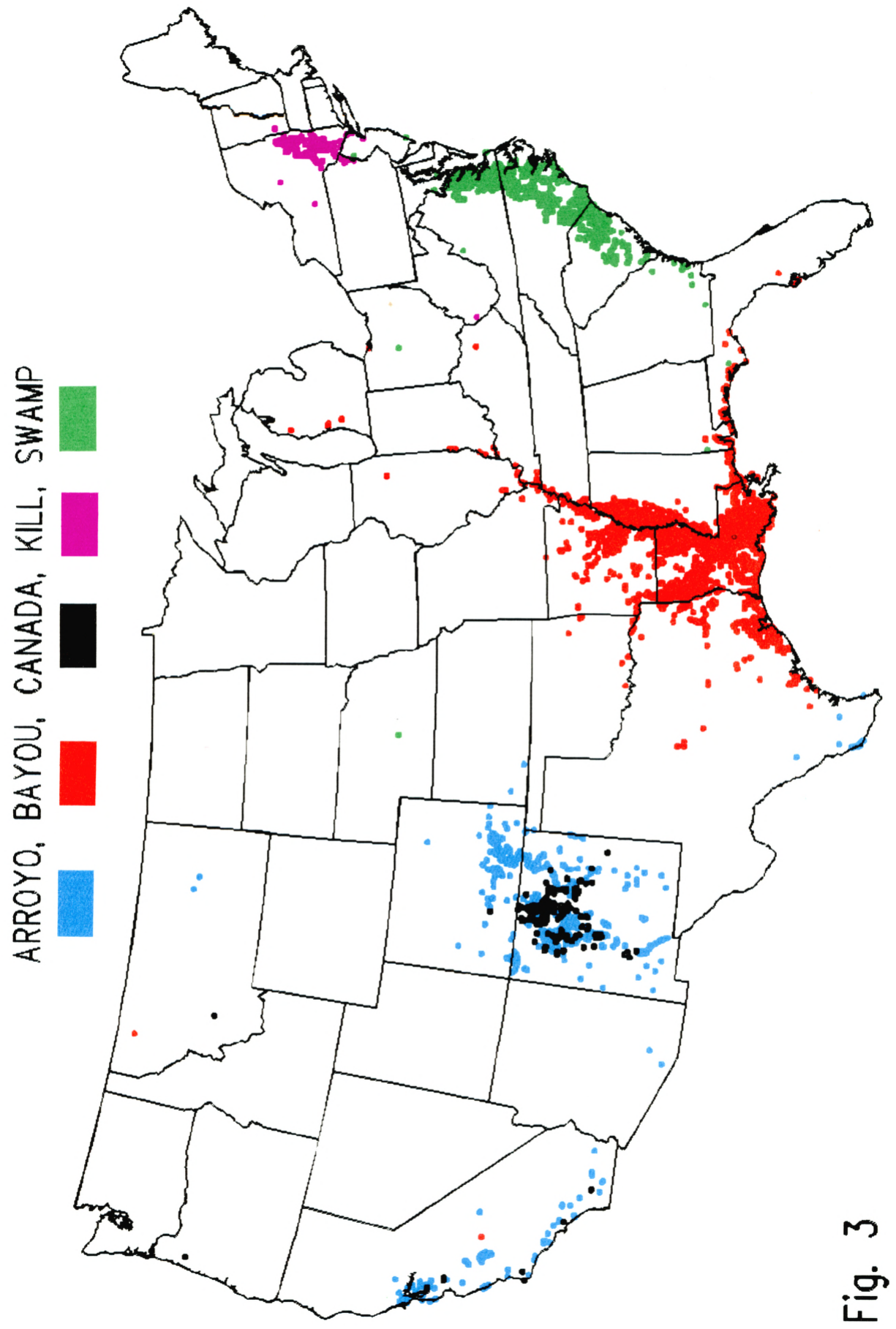


342 Jon C. Campbell

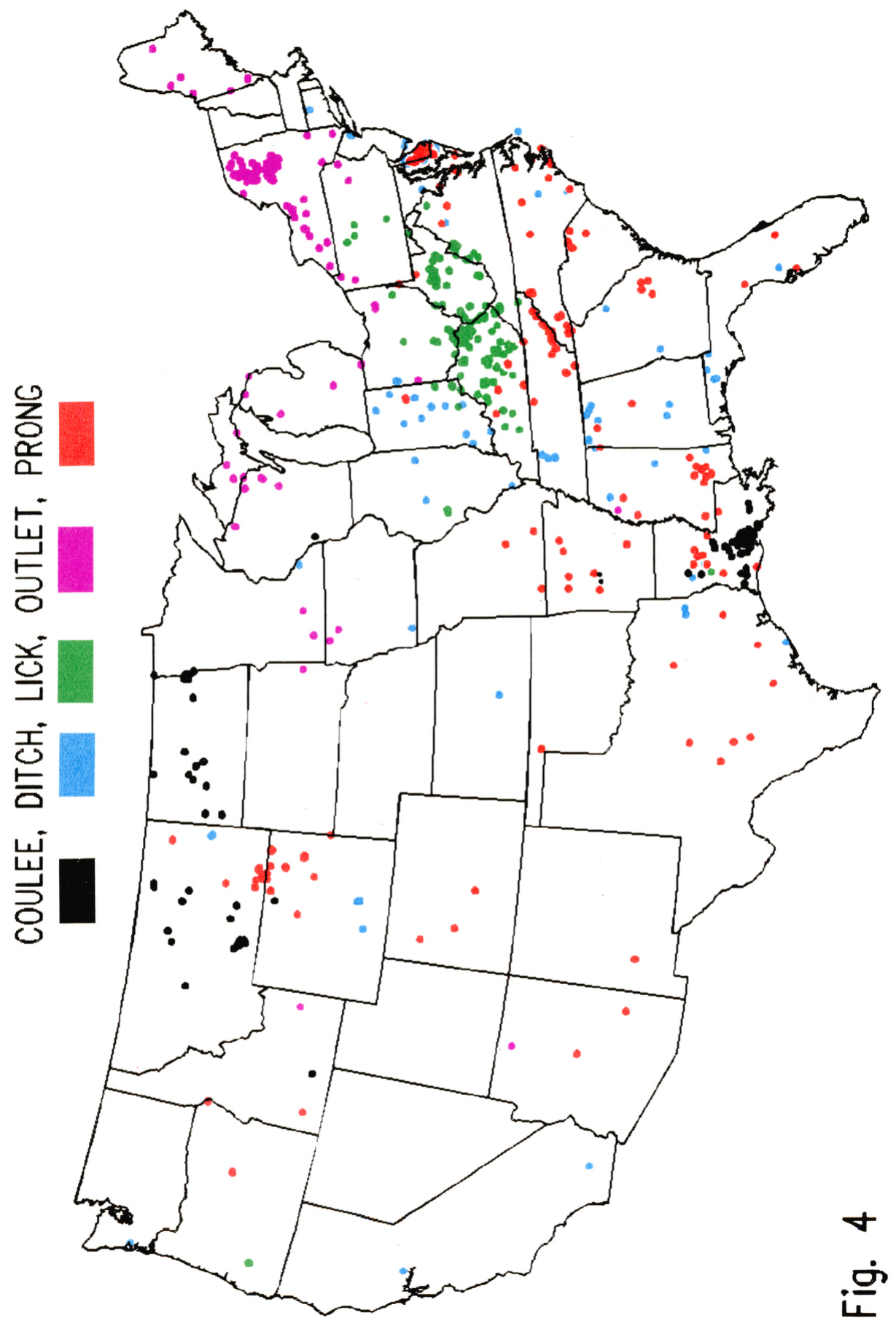


Fork (Fig. 2) [U.S., 2.0\%; West Virginia, 13.4\%]

The term fork, along with the similar terms branch and prong, form a subgroup of stream generics that can function as either directional terms within a stream name (e.g., Left Fork Rocky Creek) or as the full generic (e.g., Harman Fork). As a complete generic term, fork is most common in the stream names of West Virginia and Kentucky.

Bayou (Fig. 3) [U.S., 1.2\%; Louisiana, 39.5\%]

In his 1954 study of the term bayou, Robert C. West examined the usage of this term from a historical perspective and determined that its application to streams in the Mississippi delta dates from the earliest French settlement in the area at the close of the seventeenth century. He concurred with William A. Read (xii) that the word bayou is derived from the French translation of the Choctaw word bayuk, meaning a sluggish stream or river. Of the twenty most common stream terms, then, bayou is the only one that stems from a Native American language. Modern applications of the term to several types of features share the connotation of a sluggish or stagnant water body, except in east Texas and parts of Arkansas and Oklahoma where the it refers to full-flowing streams and would seem to be interchangeable with creek. In Louisiana the term bayou is even more common in stream names $(39.5 \%)$ than the ubiquitous creek $(30.0 \%)$.

Wash (Fig. 2) [U.S., 0.8\%; Arizona, 47.7\%]

The $D A E$ defines the term wash as "the dry bed of an intermittent stream." This definition, common in the western United States, may well be related to an older English sense of the word given in the $O E D$ as "a low-lying tract of ground, often flooded, and interspersed with shallow pools and marshes." Wash, arroyo, and cañada constitute a class of terms common in the arid regions of the West that connote an intermittent stream and often apply to the valley as well as to the water in it.

Slough (Fig. 2) [U.S., 0.8\%; Arkansas, 3.3\%]

The term slough has several connotations throughout the United States. In parts of the country it is applied to side channels of rivers with stagnant or slow moving water, as in the name Running Slough in Fulton County, Kentucky. Other applications of the word slough are to channels of slow-moving water in coastal marshlands and to small marshy areas. Slu, slue, and slew are alternate spellings. The distribution of this stream term across the country is wide, but shallow. 
Stream (Fig. 2) [U.S., 0.5\%; Hawaii, 95.2\%]

The word stream, used in this paper to refer to a broad class of geographic features, also functions more particularly as a generic term. It is the generic term in more than $95 \%$ of Hawaiian stream names. Possibly it was introduced there by missionaries from New England where the term is fairly common, especially in Maine.

Drain (Fig. 2) [U.S., 0.4\%; Michigan, 16.8\%]

The term drain is most frequently found in the stream names of the formerly swampy tracts of southeast Michigan, but according to definitions and citations in the $D A E$ and the $O E D$, the use of the term does not necessarily imply human alteration of a watercourse.

Arroyo (Fig. 3) [U.S., 0.3\%; New Mexico, 24.2\%]

The term arroyo may refer either to a stream or to the dry bed of a stream. This term forms the generic element in more than $24 \%$ of New Mexico's stream names and occurs more than 100 times in the stream names of Colorado and California.

Swamp (Fig. 3) [U.S., 0.3\%; South Carolina, 4.8\%]

The $O E D$ and $D A E$ give the conventional definitions of the term swamp as a "marsh" or a "bog," but neither source mentions that the term may also be applied to a watercourse. G. D. McJimsey has suggested that in some places in Virginia the term was originally applied to the area occupied by the swamp and the stream. After the lowland was drained, the term swamp survived in the narrowed sense of watercourse (McJimsey 28). The use of this term as a stream generic is generally restricted to the Atlantic Coastal Plain from the Chesapeake Bay to Georgia. On a percentage basis, the stream names of South Carolina use this term most often, although there are about twice as many cases of its use in North Carolina. An example is Bachelors Delight Swamp, a stream in Onslow County, North Carolina.

Cañada (Fig. 3) [U.S., 0.1\%; New Mexico, 11.4\%]

The $O E D$ and the $D A E$ define the term cañada similarly as "a narrow valley or glen; a ravine or small cañon." No reference consulted listed a hydrographic sense of this term, but according to GNIS data the term is applied to more than 200 streams on USGS topographic maps. Cañada is the generic term in more than $11 \%$ of New Mexico's stream names and there are nine occurrences in California. 
Prong (Fig. 4) [U.S., 0.1\%; Delaware, 5.1\%]

Like branch and fork, the term prong may serve as a directional term within a stream name or as a complete generic element.

Lick (Fig. 4) [U.S., 0.1\%; Kentucky, 0.7\%]

The word lick is often found in the names of streams that pass by a place where salt or salt earth is found and licked by animals. As a stream term lick is usually part of a compound specific, as in the name Blue Lick Branch (Franklin County, Alabama), but it is rare as a complete generic term, as in the name Slate Lick (Delaware County, Ohio).

Kill (Fig. 3) [U.S., 0.1\%; New York, 3.2\%]

Kill is a stream term of Dutch ancestry that is found most frequently in New York. The term is rare in adjacent states and is virtually unknown elsewhere.

Ditch (Fig. 4) [U.S., 0.1\%; Delaware, 12.0\%]

Ditch, like drain, is an ambiguous term that may connote some degree of manmade improvement in the natural drainage. Placename authority H. F. Raup has written that in Ohio the term is applied to faint natural drainage channels that have been deepened in efforts to drain swampy low ground (Raup 164).

Outlet (Fig. 4) [U.S., 0.1\%; New York, 1.8\%]

The term outlet is occasionally employed, most often in upper New York State, in the names of streams that empty lakes or ponds.

Coulee (Fig. 4) [U.S., less than 0.1\%; North Dakota, 2.6\%]

The term coulee, a geographic term of French origin, is believed to be an Americanism, ${ }^{5}$ since it is not used as a toponymic term in France. In Montana and North Dakota the term coulee refers more often to valleys than to streams. In these states all stream names that have coulee as the generic follow the usual English specific-generic word order. In Louisiana, where the term coulee is applied exclusively to streams, about one-half of the names are in English word order and the other half have a French generic-specific word order. 


\section{Conclusions}

The promise of extensively plotting stream generics would seem to be that the mapped pattern of a given term will correspond to the area settled by a particular language or culture group. Where European and American settlers made their homes in the wilderness, streams must have been among the first natural features that they named because the knowledge of water features was fundamental in a frontier setting. Streams were first used as landmarks for land and water navigation (Raup 164; Jordan and Kaups 77) and then for property boundaries. Streams provided vital drinking water for people and livestock. They were essential for transportation, communication, water power, hunting and fishing, and, sometimes, for irrigation. ${ }^{6}$ Consequently, stream names had to be commonly understood in a frontier community. A widely held tenet in historical geography, known as the principle of initial occupance, ${ }^{7}$ holds that the first effective, self-perpetuating settlement in an area, no matter how small the original assembly, determines the later social and cultural geography of that area. That the first effective settlement group should leave its cultural imprint on the stream generic terms of a region might appear, initially, to be a justifiable assumption.

This supposition holds for several non-English generics. Outlines shown by the plotted terms arroyo and cañada (Fig. 3) roughly follow the known pattern of Spanish-Mexican settlement in California, New Mexico, and southern Colorado before the acquisition of this region by the United States after the Mexican War. ${ }^{8}$ The plotted overlay of stream names containing the word bayou (Fig. 3) correlates to areas of historical French influence, principally in the Mississippi Valley. ${ }^{9}$ The plot of the term kill (Fig. 3) shows that this Dutch word endures in stream names in the Hudson Valley, the core settlement area of New Netherlands (Wacker 4).

Conversely, many other stream terms must have existed in the languages of various ethnic groups but have not survived on current maps. Two of the many possible examples of this circumstance will serve to establish an obvious point. German-speaking pioneers were the first settlers in the Shenandoah Valley of Virginia in 1726, and they continued to form a large part of the population there through the eighteenth century (Mitchell 27, 43), but no generic terms of German origin linger in Virginia stream names. Scandinavians made up a substantial portion of the first wave of settlers in Clay County, Dakota Territory (now South Dakota), yet there, too, English terms prevailed in the stream nomenclature (Ostergren 74). It is not very surprising that English terminology should have been employed for geographic names by English-speaking surveyors and government officials who drew maps, located properties, and recorded deeds. The official sanc- 
tion established the written name, and any oral use of other terms probably ceased with increased acculturation of the language group. ${ }^{10}$

As a device for research in the field of historical geography, the distribution of generic terms should be considered as an indicative but not a correlative tool; that is, the existence in an area of a certain stream generic term that is identified with a culture group suggests the historical presence of that group, but the absence of the term is not conclusive evidence that the group never inhabited the region. As noted above, the generic terms that are used in a spoken language or dialect may never appear in official documents or on published maps. Furthermore, the topographic vocabulary of subsequent settlement groups may erase previously existing generic terms. This has been the fate of the term kill on Long Island. If the modern range of this term were to be considered the extent of Dutch settlement in the Northeast, then the western end of Long Island would be mistakenly excluded. There all the places the Dutch referred to as kill are now known by other generic terms. ${ }^{11}$ In other circumstances more recent generic terms used by a later culture group may subsume older terms in stream names. The name Schuylkill River is a model example of this process. In this instance the older Dutch term kill is embedded in the specific component of the name and the more current term river forms the generic element. There are hundreds of other similar cases, most notably with the generic creek, as in the names Bog Branch Creek and Seco Arroyo Creek.

A key point in evaluating the modern distribution of stream terms as historical evidence is whether present-day usage accurately reflects past usage. The national scope of this project has precluded the examination of primary sources of historical toponymy, such as initial descriptions of surveyors, early deeds, and old large-scale maps, that would provide a baseline for considering when and how much given stream terms have changed through time. Such an intensive study would have to be conducted at a very local level. Two factors, at least, certainly work to preserve a stream generic term and protect it from cultural influences that change other aspects of language. One factor is the pervasive use of streams as property markers, especially in the metes and bounds system of indicating land boundaries by reference to natural objects. Even when the meaning of one generic in a stream name can easily be replaced by another term, the original term is not likely to be supplanted while it is used as a name in a land title. ${ }^{12} \mathrm{~A}$ second, more theoretical factor is the linguistic protection that a generic term is afforded by its existence as an element of a geographic name. Names, writes W. F. H. Nicolaisen, have a "power of survival" that other words do not have. Names are durable because "they can be meaningful as names even if they have become meaningless as words" (4). 
Clearly creek is the historically ascendant stream term. It appears to have greatly increased in popularity since about 1800 . Assuming for a moment that the year of a state's entry into the Union provides a rough guide to the time of settlement, and excluding Hawaii, Alaska, Arizona, and New Mexico as having anomalous settlement histories, the states whose stream names employ creek as the generic term less than $30 \%$ of the time were all states before $1800 .{ }^{13}$ Overlooking Georgia at $61.4 \%$, a state that was settled much later than the other former colonies, none of the rest of the original thirteen states has more than $50 \%$ creeks in its stream generics compared to the national average of $60.9 \%$. On the other hand, of the states where the term creek appears in more than $90 \%$ of stream names, only one, Oregon, achieved statehood before 1875 (in 1859). The popularity of creek grew at the expense of other terms common in eastern states, such as run, branch, and brook, even though these terms are just as applicable to western streams.

The demonstrated distribution patterns of stream generics invite further study. For instance, the terms branch and prong in New Jersey, Pennsylvania, and Maryland are not nearly as common as they are in neighboring Delaware. The combination of percentages of stream generic terms in Delaware is more similar to that of Tennessee. Although a linguistic thread between the two areas is unlikely, what factors account for the coincident use of the uncommon term prong in Delaware and eastern Tennessee? Why did the term brook not flourish outside of New England, New York, and New Jersey? In the places where New Englanders settled across the Midwest and West, there must have been many unnamed streams that suited the connotation of this term. How did the term creek come to predominate in later American settlement history? Lewis and Clark, Virginia men both, employed the term exclusively for the names of lesser streams during their historic expedition. Did their practice influence subsequent American cartography and toponymy? Or was the use of the term creek increasing in any case in the early nineteenth century due, perhaps, to a shared literary or educational experience of the namers? Scholars from the fields of American history, cultural and historical geography, toponymy, linguistics, folklore, and related disciplines may wish to formulate their own programmed inquiries for the data in the Geographic Names Information System. 


\section{Notes}

1. This is a revised version of a paper presented at the meeting of the Association of American Geographers in Toronto in April 1990. I am grateful to John Findley and Lou Yost of the U.S. Geological Survey for their technical assistance in producing the termdistribution plots. Financial support from the USGS has made possible the color reproduction of the plots.

2. The U.S. Geological Survey has recorded more than 100 different stream terms from Survey maps (Orth and Payne 112-14).

3. Gritzner has stated that, in stream names on the eastern shore (Delaware, Maryland, Virginia), the distinction in the use of the terms river, creek, branch, and run was based on the navigational qualities of the stream (236-37).

4. The GNIS at the U.S. Geological Survey is made up of several data bases related to geographic names, but the National Geographic Names Base is by far the largest and most important. The use of this particular data base is assumed in any following reference to the GNIS.

5. Coulee is an Americanism in the broad sense of the word. The term is also applied to terrain features in western Canada, principally in southern Alberta and southwestern Saskatchewan (Rayburn 95).

6. In the Far West the doctrine of appropriation allowed priority to exploit a stream to the first person who came to it and claimed part of its water (Sauder 411).

7. A principle enunciated separately by Kniffen (551) and Zelinsky (Cultural 13).

8. See Bolton and the two articles by Nostrand.

9. See West, McDermott.

10. One intriguing case of a Dutch stream generic other than kill that survives on USGS maps is Feuri Spruyt, a small stream in Albany County, New York.

11. No present use of the term is found on federal government maps, according to the GNIS data. See also Hale.

12. Mitchell notes that almost all references to colonial land grants were made in relation to the nearest stream (43).

13. This statement is true also for West Virginia and Maine, which were sections of Virginia and Massachusetts in 1800.

\section{Works Cited}

Bolton, H. E. The Spanish Borderlands: A Chronicle of Old Florida and the Southwest. New Haven: Yale UP, 1921.

Burrill, Meredith F. "Toponymic Generics I \& II." Names 4.3 and 4.4 (1956): 129-37; 226-40

A Dictionary of American English on Historical Principles. William A. Craigie and James R. Hulbert, eds. 4 vols. Chicago: U of Chicago $P, 1938-1944$

Gritzner, Janet H. "Seventeenth Century Generic Place-Names: Culture and Process on the Eastern Shore." Names 20.4 (1972): 231-39.

Hale, Edward Everett, Jr. "Dialectical Evidence in the Place-Names of Eastern New York." American Speech 5 (1929): 154- 67. 
Jordan, Terry G., and Matti Kaups. The American Backwoods Frontier: An Ethnic and Ecological Interpretation. Baltimore: Johns Hopkins UP, 1989.

Kniffen, Fred B. "Folk Housing: Key to Diffusion." Annals of the Association of American Geographers 55 (1965): 549-77.

Kurath, Hans. A Word Geography of the Eastern United States. Ann Arbor, MI: U of Michigan P, 1949.

McDermott, John Francis, ed. The French in the Mississippi Valley. Urbana: U of Illinois $P, 1965$.

McJimsey, George Davis. Topographic Terms in Vinginia. New York: Columbia UP, 1940.

Mitchell, Robert D. Commercialism and Frontier: Perspectives on the Early Shenandoah Valley. Charlottesville: UP of Virginia, 1977.

The Oxford English Dictionary. 13 vols. 1889-1933

Nicolaisen, W. F. H. Scottish Place-Names. London: B. T. Batsford, 1976.

Nostrand, R. L. "The Hispanic-American Borderland: Delimitation of an American Culture Region." Annals of the Association of American Geographers 60 (1970): 638-61.

- "The Hispano Homeland in 1900." Annals of the Association of American Geographers 70 (1980): 382-96.

Orth, Donald J., and Roger L. Payne. The National Geographic Names Data Base: Phase II Instructions. U.S. Geological Survey Circular 1011. Washington, DC: Government Printing Office, 1987.

Ostergren, Robert C. "Prairie Bound: Migration Patterns to a Swedish Settlement on the Dakota Frontier." Ethnicity on the Great Plains. Frederick C. Luebke, ed. Lincoln: U of Nebraska P, 1980. 73-91.

Raup, H. F. "The Names of Ohio's Streams." Names 5.3 (1957): 162-68. Rayburn, J. Alan. "English Geographical Names in Canada with Generic Terms of French Origin." The Canadian Cartographer 7 (1970): 88-104.

Read, William A. Louisiana Place-Names of Indian Origin. Louisiana State University Bulletin (ns) 19. Baton Rouge: Louisiana State U, 1927.

Sauder, Robert A. "Sod Land Versus Sagebrush: Early Land Appraisal and Pioneer Settlement in an Arid Intermountain Frontier." Journal of Historical Geography 15 (1989): 402-19.

Wacker, Peter O. "The Dutch Culture Area in the Northeast, 16091800." New Jersey History 104 (1986): 1-21.

West, Robert C. "The Term 'Bayou' in the United States: A Study in the Geography of Place-Names." Annals of the Association of American Geographers 44 (1954): 463-74. 
Zelinsky, Wilbur. The Cultural Geography of the United States. Englewood Cliffs, NJ: Prentice Hall, 1973.

. "Some Problems in the Distribution of Generic Terms in the PlaceNames of the Northeastern United States." Annals of the Association of American Geographers 45 (1955): 319-49.

\section{Appendix}

\section{Stream Generic Terms \\ by Term}

\section{Abbreviation Key:}

all streams - the number of stream names in the state according to GNIS data all cases - the number of stream names in the state that contain the listed term not genr - the number of stream names that contain the term but do not use it as the generic, e.g., West Fork Johnson Branch

as genr - the number of stream names that do use the term as the generic, e.g., West Branch Johnson Fork

all \% - the percentage of stream names in the state that contain the term genr \% - the percentage of stream names in the state that use the term as the generic

$\begin{array}{ccccccc} & \text { all } & \text { all } & \text { not } & \text { as } & \text { all } & \text { genr } \\ \text { State } & \text { streams } & \text { cases } & \text { genr } & \text { genr } & \% & \%\end{array}$

\section{CREEK}

$\begin{array}{lrrrrrr}\text { Montana } & 8995 & 8681 & 1 & 8680 & 96.5 & 96.5 \\ \text { Idaho } & 8941 & 8629 & 1 & 8628 & 96.5 & 96.5 \\ \text { Wyoming } & 5271 & 4985 & 0 & 4985 & 94.6 & 94.6 \\ \text { Oregon } & 11587 & 10928 & 6 & 10922 & 94.3 & 94.3 \\ \text { South Dakota } & 1347 & 1267 & 0 & 1267 & 94.1 & 94.1 \\ \text { Washington } & 5959 & 5451 & 3 & 5448 & 91.5 & 91.4 \\ \text { Colorado } & 5350 & 4881 & 1 & 4880 & 91.2 & 91.2\end{array}$




\begin{tabular}{|c|c|c|c|c|c|c|}
\hline $\begin{array}{c}\text { State } \\
\text { (CREEK, cont.) }\end{array}$ & $\begin{array}{c}\text { all } \\
\text { streams }\end{array}$ & $\begin{array}{r}\text { all } \\
\text { cases }\end{array}$ & $\begin{array}{l}\text { not } \\
\text { genr }\end{array}$ & $\begin{array}{l}\text { as } \\
\text { genr }\end{array}$ & $\begin{array}{l}\text { all } \\
\%\end{array}$ & $\begin{array}{c}\text { genr } \\
\%\end{array}$ \\
\hline Kansas & 2488 & 2240 & 0 & 2240 & 90.0 & 90.0 \\
\hline Oklahoma & 3073 & 2759 & 0 & 2759 & 89.8 & 89.8 \\
\hline California & 9555 & 8513 & 7 & 8506 & 89.1 & 89.0 \\
\hline Nebraska & 1426 & 1257 & 0 & 1257 & 88.1 & 88.1 \\
\hline Utah & 2366 & 2023 & 1 & 2022 & 85.5 & 85.5 \\
\hline North Dakota & 622 & 520 & 0 & 520 & 83.6 & 83.6 \\
\hline Nevada & 2028 & 1671 & 4 & 1667 & 82.4 & 82.2 \\
\hline Iowa & 1962 & 158 & 1 & 1585 & 80.8 & 80.8 \\
\hline Alaska & 8526 & 6890 & 13 & 6877 & 80.8 & 80.7 \\
\hline Wisconsin & 2965 & 2343 & 4 & 2339 & 79.0 & 78.9 \\
\hline Texas & 11259 & 7782 & 4 & 7778 & 69.1 & 69.1 \\
\hline Minnesota & 1907 & 1320 & 4 & 1316 & 69.2 & 69.0 \\
\hline Illinois & 2560 & 1764 & 2 & 1764 & 69.0 & 68.9 \\
\hline Michigan & 4346 & 2942 & 10 & 2932 & 67.7 & 67.5 \\
\hline Arkansas & 4676 & 2970 & 1 & 2969 & 63.5 & 63.5 \\
\hline Georgia & 5506 & 3381 & 0 & 3381 & 61.4 & 61.4 \\
\hline United States & 221667 & 135054 & 107 & 134947 & 60.9 & 60.9 \\
\hline Missouri & 4907 & 2883 & 1 & 2882 & 58.8 & 58.7 \\
\hline Mississippi & 4556 & 2663 & 1 & 2662 & 58.5 & 58.4 \\
\hline Florida & 2936 & 1628 & 3 & 1625 & 55.4 & 55.3 \\
\hline Alabama & 6506 & 3543 & 1 & 3542 & 54.5 & 54.4 \\
\hline Indiana & 3466 & 1891 & 5 & 1886 & 54.6 & 54.4 \\
\hline South Carolina & 3535 & 1727 & 0 & 1727 & 48.9 & 48.9 \\
\hline Arizona & 2267 & 109 & 3 & 1091 & 48.3 & 48.1 \\
\hline North Carolina & 9129 & 34386 & 3 & 4383 & 48.0 & 48.0 \\
\hline New York & 4382 & 1997 & $\mathbf{0}$ & 1997 & 45.6 & 45.6 \\
\hline New Mexico & 2065 & 922 & 1 & 921 & 44.6 & 44.6 \\
\hline Virginia & 7159 & 3113 & 0 & 3113 & 43.5 & 43.5 \\
\hline Maryland & 1795 & 766 & $\mathbf{0}$ & 766 & 42.7 & 42.7 \\
\hline Ohio & 3491 & 1388 & 1 & 1387 & 39.7 & 39.7 \\
\hline Tennessee & 9224 & 3551 & 8 & 3543 & 38.5 & 38.4 \\
\hline New Jersey & 1345 & 478 & 2 & 476 & 35.5 & 35.4 \\
\hline Louisiana & 4162 & 1252 & 2 & 1250 & 30.1 & 30.0 \\
\hline Kentucky & 11247 & 3243 & 10 & 3233 & 28.8 & 28.7 \\
\hline Pennsylvania & 6691 & 1855 & 2 & 1853 & 27.7 & 27.7 \\
\hline Dist. Columbia & 19 & 5 & 0 & 5 & 26.3 & 26.3 \\
\hline Delaware & 433 & 89 & 0 & 89 & 20.6 & 20.6 \\
\hline West Virginia & 8468 & 1452 & 0 & 1452 & 17.1 & 17.1 \\
\hline Massachusetts & 2057 & 136 & 1 & 135 & 6.6 & 6.6 \\
\hline Rhode Island & 254 & 15 & 0 & 15 & 5.9 & 5.9 \\
\hline Vermont & 1263 & 52 & 0 & 52 & 4.1 & 4.1 \\
\hline Connecticut & 1468 & 46 & 0 & 46 & 3.1 & 3.1 \\
\hline Maine & 3935 & 76 & 0 & 76 & 1.9 & 1.9 \\
\hline New Hampshire & 1684 & 18 & $\mathbf{0}$ & 18 & 1.1 & 1.1 \\
\hline
\end{tabular}

\section{BRANCH}

$\begin{array}{lrrrrrr}\text { Tennessee } & 9224 & 5252 & 10 & 5242 & 56.9 & 56.8 \\ \text { Kentucky } & 11247 & 6043 & 23 & 6020 & 53.7 & 53.5 \\ \text { Delaware } & 433 & 208 & 5 & 203 & .48 .0 & 46.9\end{array}$


Stream Generic Terms 353

State

$\begin{array}{cccc}\text { all all not as } & \end{array}$

all
$\%$

(BRANCH, cont.)

\begin{tabular}{|c|c|c|c|c|c|c|}
\hline Alabama & 6506 & 2769 & 9 & 2760 & 42.6 & $\begin{array}{l}42.4 \\
412\end{array}$ \\
\hline North Carolina & 9129 & 3784 & 19 & 3765 & 41.5 & 41.2 \\
\hline South Carolina & 3535 & 143 & 9 & 1428 & 40.7 & 40.4 \\
\hline Georgia & 5506 & 1885 & 15 & 1870 & 34.2 & 34.0 \\
\hline Missouri & 4907 & 1652 & 28 & 1624 & 33.7 & 33.1 \\
\hline Dist. Columbia & 19 & 6 & 0 & 6 & 31.6 & 31.6 \\
\hline Virginia & 7159 & 2328 & 72 & 2256 & 32.5 & 31.5 \\
\hline Florida & 2936 & 916 & 24 & 892 & 31.2 & 30.4 \\
\hline Mississippi & 4556 & 1281 & 21 & 1260 & 28.1 & 27.7 \\
\hline Texas & 11259 & 2847 & 45 & 2802 & 25.3 & 24.9 \\
\hline Maryland & 1795 & 479 & 45 & 434 & 26.7 & 24.2 \\
\hline Arkansas & 4676 & 1078 & 8 & 1070 & 23.1 & 22.9 \\
\hline West Virginia & 8468 & 1871 & 23 & 1848 & 22.1 & 21.8 \\
\hline Louisiana & 4162 & 892 & 10 & 882 & 21.4 & 21.2 \\
\hline United States & 221667 & 39516 & 2776 & 36740 & 17.8 & 16.6 \\
\hline New Jersey & 1345 & 273 & 53 & 220 & 20.3 & 16.4 \\
\hline Illinois & 2560 & 477 & 63 & 414 & 18.6 & 16.2 \\
\hline Indiana & 3466 & 556 & 47 & 509 & 16.0 & 14.7 \\
\hline Oklahoma & 3073 & 267 & 27 & 240 & 8.7 & 7.8 \\
\hline Iowa & 1962 & 193 & 53 & 140 & 9.8 & 7.1 \\
\hline Kansas & 2488 & 234 & 107 & 127 & 9.4 & 5.1 \\
\hline Nebraska & 1426 & 130 & 70 & 60 & 9.1 & 4.2 \\
\hline Wisconsin & 2965 & 254 & 148 & 106 & 8.6 & 3.6 \\
\hline Vermont & 1263 & 96 & 55 & 4 & 7.6 & 3.2 \\
\hline Ohio & 3494 & 191 & 103 & 88 & 5.5 & 2.5 \\
\hline Pennsylvania & 6691 & 473 & 310 & 163 & 7.1 & 2.4 \\
\hline New Hampshire & 1684 & 86 & 68 & 18 & 5.1 & 1.1 \\
\hline Michigan & 4346 & 353 & 322 & 31 & 8.1 & 0.7 \\
\hline Maine & 3935 & 274 & 251 & 23 & 7.0 & 0.6 \\
\hline New York & 4382 & 198 & 171 & 27 & 4.5 & 0.6 \\
\hline Minnesota & 1907 & 90 & 78 & 12 & 4.7 & 0.6 \\
\hline Oregon & 11587 & 100 & 40 & 60 & 0.9 & 0.5 \\
\hline California & 9555 & 131 & 105 & 26 & 1.4 & 0.3 \\
\hline Colorado & 5350 & 58 & 42 & 16 & 1.1 & 0.3 \\
\hline Massachusetts & 2057 & 54 & 48 & 6 & 2.6 & 0.3 \\
\hline Wyoming & 5271 & 47 & 29 & 18 & 0.9 & 0.3 \\
\hline North Dakota & 622 & 40 & 38 & 2 & 6.4 & 0.3 \\
\hline South Dakota & 1347 & 38 & 35 & 3 & 2.8 & 0.2 \\
\hline Hawaii & 505 & 5 & 4 & 1 & 1.0 & 0.2 \\
\hline Connecticut & 1468 & 42 & 41 & 1 & 2.9 & 0.1 \\
\hline Montana & 8995 & 38 & 25 & 13 & 0.4 & 0.1 \\
\hline Washington & 5959 & 36 & 33 & 3 & 0.6 & 0.1 \\
\hline Utah & 2366 & 10 & 7 & 3 & 0.4 & 0.1 \\
\hline Nevada & 2028 & 9 & 6 & 3 & 0.4 & 0.1 \\
\hline Idaho & 8941 & 13 & 13 & 0 & 0.1 & 0.0 \\
\hline Alaska & 8526 & 12 & 10 & 2 & 0.1 & 0.0 \\
\hline Arizona & 2267 & 5 & 4 & 1 & 0.2 & 0.0 \\
\hline New Mexico & 2065 & 3 & 2 & 1 & 0.1 & 0.0 \\
\hline Rhode Island & 254 & 2 & 2 & 0 & 0.8 & 0.0 \\
\hline
\end{tabular}




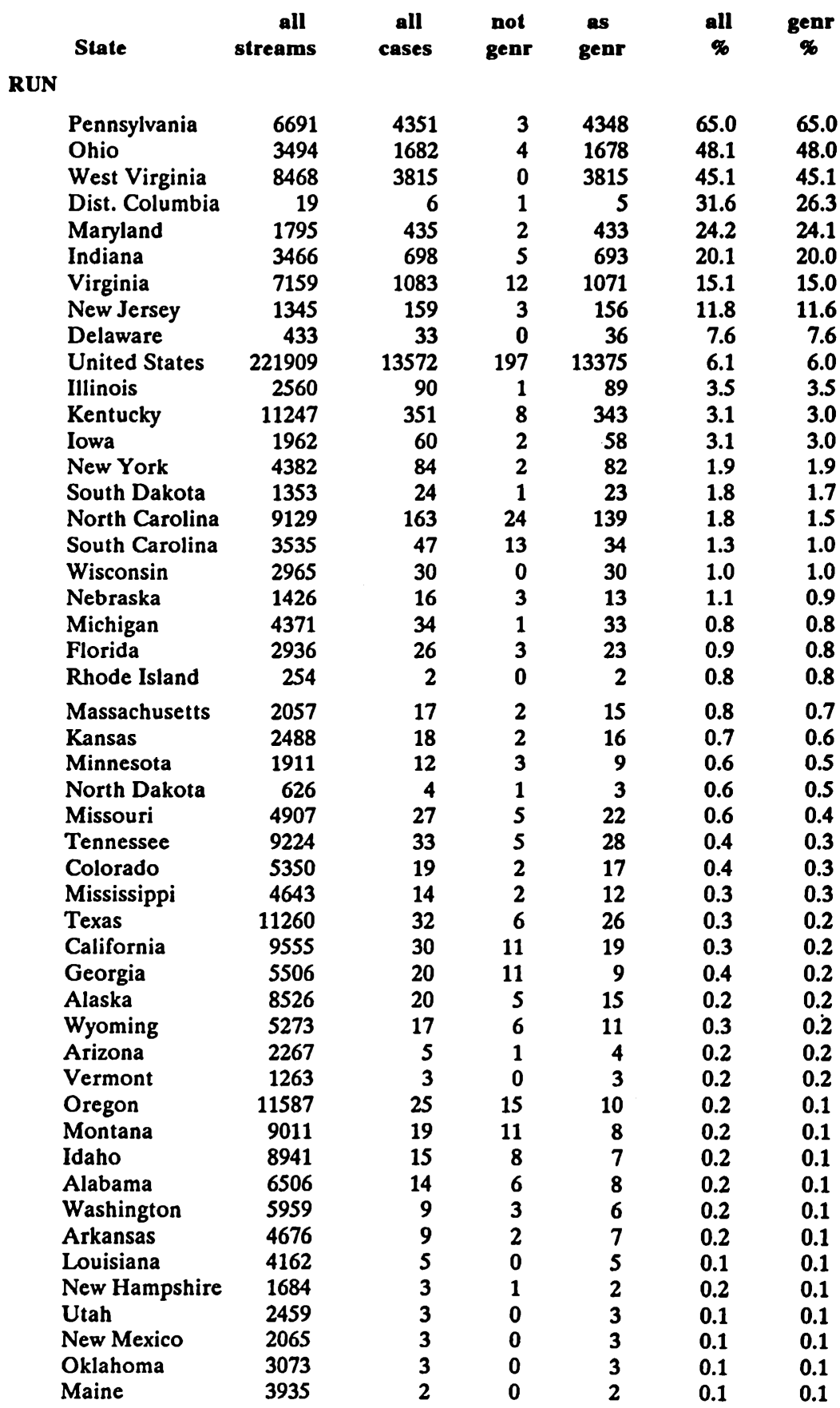


Stream Generic Terms 355

$\begin{array}{ccccccc} & \text { all } & \text { all } & \text { not } & \text { as } & \text { all } & \text { genr } \\ \text { State } & \text { streams } & \text { cases } & \text { genr } & \text { genr } & \% & \%\end{array}$

(RUN, cont.)

Connecticut 1468

Nevada 2032

$\begin{array}{lllll}1 & 0 & 1 & 0.1 & 0.1 \\ 1 & 1 & 0 & 0.0 & 0.0\end{array}$

\section{BROOK}

$\begin{array}{lrrrrrr}\text { New Hampshire } & 1684 & 1453 & 0 & 1453 & 86.3 & 86.3 \\ \text { Connecticut } & 1468 & 1268 & 3 & 1265 & 86.4 & 86.2 \\ \text { Vermont } & 1263 & 1039 & 0 & 1039 & 82.3 & 82.3 \\ \text { Massachusetts } & 2057 & 1632 & 1 & 1631 & 79.3 & 79.3 \\ \text { Maine } & 3935 & 2996 & 2 & 2994 & 76.1 & 76.1 \\ \text { Rhode Island } & 254 & 185 & 0 & 185 & 72.8 & 72.8 \\ \text { New York } & 4382 & 1749 & 0 & 1749 & 39.9 & 39.9 \\ \text { New Jersey } & 1345 & 390 & 2 & 388 & 29.0 & 28.8 \\ \text { Minnesota } & 1907 & 114 & 1 & 113 & 6.0 & 5.9 \\ \text { United States } & 221660 & 11423 & 33 & 11390 & 5.2 & 5.1 \\ \text { Indiana } & 3466 & 118 & 2 & 116 & 3.4 & 3.3 \\ \text { Pennsylvania } & 6691 & 174 & 2 & 172 & 2.6 & 2.6 \\ \text { Wisconsin } & 2965 & 74 & 0 & 74 & 2.5 & 2.5 \\ \text { Michigan } & 4346 & 65 & 5 & 60 & 1.5 & 1.4 \\ \text { Ohio } & 3494 & 24 & 0 & 24 & 0.7 & 0.7 \\ \text { Delaware } & 433 & 2 & 0 & 2 & 0.5 & 0.5 \\ \text { Maryland } & 1795 & 8 & 0 & 8 & 0.4 & 0.4 \\ \text { Colorado } & 5350 & 18 & 3 & 15 & 0.3 & 0.3 \\ \text { North Dakota } & 622 & 2 & 0 & 2 & 0.3 & 0.3 \\ \text { Oregon } & 11587 & 22 & 1 & 21 & 0.2 & 0.2 \\ \text { Alabama } & 6506 & 16 & 0 & 16 & 0.2 & 0.2 \\ \text { Iowa } & 1962 & 4 & 0 & 4 & 0.2 & 0.2 \\ \text { Illinois } & 2560 & 4 & 0 & 4 & 0.2 & 0.2 \\ \text { Virginia } & 7159 & 9 & 1 & 8 & 0.1 & 0.1 \\ \text { California } & 9555 & 8 & 1 & 7 & 0.1 & 0.1 \\ \text { Washington } & 5959 & 6 & 0 & 6 & 0.1 & 0.1 \\ \text { Florida } & 2936 & 4 & 0 & 4 & 0.1 & 0.1 \\ \text { Kansas } & 2488 & 4 & 1 & 3 & 0.2 & 0.1 \\ \text { South Dakota } & 1347 & 2 & 0 & 2 & 0.1 & 0.1 \\ \text { Utah } & 2366 & 2 & 0 & 2 & 0.1 & 0.1 \\ \text { Nebraska } & 1426 & 1 & 0 & 1 & 0.1 & 0.1 \\ \text { North Carolina } & 9129 & 5 & 1 & 4 & 0.1 & 0.0 \\ \text { West Virginia } & 8468 & 5 & 2 & 3 & 0.1 & 0.0 \\ \text { Texas } & 11259 & 4 & 2 & 2 & 0.0 & 0.0 \\ \text { Montana } & 8995 & 3 & 0 & 3 & 0.0 & 0.0 \\ \text { Idaho } & 8941 & 2 & 1 & 1 & 0.0 & 0.0 \\ \text { Missouri } & 4900 & 2 & 0 & 2 & 0.0 & 0.0 \\ \text { Wyoming } & 5271 & 2 & 0 & 2 & 0.0 & 0.0 \\ \text { New Mexico } & 2065 & 1 & 0 & 1 & 0.0 & 0.0 \\ \text { Kentucky } & 11247 & 1 & 0 & 1 & 0.0 & 0.0 \\ \text { Arkansas } & 4676 & 1 & 0 & 1 & 0.0 & 0.0 \\ \text { Mississippi } & 4556 & 1 & 1 & 0 & 0.0 & 0.0 \\ \text { Tennessee } & 9224 & 1 & 0 & 1 & 0.0 & 0.0 \\ \text { Oklahoma } & 3073 & 1 & 1 & 0 & 0.0 & 0.0 \\ \text { Georgia } & 5506 & 1 & 0 & 1 & 0.0 & 0.0\end{array}$




\begin{tabular}{|c|c|c|c|c|c|c|}
\hline State & $\begin{array}{c}\text { all } \\
\text { streams }\end{array}$ & $\begin{array}{l}\text { all } \\
\text { cases }\end{array}$ & $\begin{array}{l}\text { not } \\
\text { genr }\end{array}$ & $\begin{array}{l}\text { as } \\
\text { genr }\end{array}$ & all & $\underset{\%}{\operatorname{genr}}$ \\
\hline \multicolumn{7}{|l|}{ RIVER } \\
\hline Minnesota & 1911 & 428 & 3 & 42 & 22.4 & 22.2 \\
\hline Rhode Island & 254 & 52 & 0 & 52 & 20.5 & 20.5 \\
\hline Alaska & 8526 & 1288 & 4 & 1284 & 15.1 & 15.1 \\
\hline Massachusetts & 2057 & 25 & 2 & 255 & 12.5 & 12.4 \\
\hline Wisconsin & 2965 & 361 & 0 & 361 & 12.2 & 12.2 \\
\hline Michigan & 4371 & 523 & 11 & 512 & 12.0 & 11.7 \\
\hline Dist. Columbia & 19 & 2 & $\mathbf{0}$ & 2 & 10.5 & 10.5 \\
\hline Connecticut & 1468 & 143 & $\mathbf{0}$ & 143 & 9.7 & 9.7 \\
\hline North Dakota & 626 & 6 & 1 & 60 & 9.7 & 9.6 \\
\hline New Hampshire & 1684 & 155 & $\mathbf{0}$ & 155 & 9.2 & 9.2 \\
\hline Vermont & 1263 & 110 & $\mathbf{0}$ & 110 & 8.7 & 8.7 \\
\hline Florida & 2936 & 204 & 2 & 202 & 6.9 & 6.9 \\
\hline Maine & 3935 & 262 & 2 & 260 & 6.7 & 6.6 \\
\hline Iowa & 1962 & 117 & $\mathbf{0}$ & 117 & 6.0 & 6.0 \\
\hline Washington & 5959 & 348 & 1 & 347 & 5.8 & 5.8 \\
\hline New Jersey & 1345 & 72 & 1 & 71 & 5.4 & 5.3 \\
\hline New York & 4382 & 215 & 0 & 215 & 4.9 & 4.9 \\
\hline Illinois & 2560 & 118 & 1 & 117 & 4.6 & 4.6 \\
\hline Delaware & 433 & 19 & 0 & 19 & 4.4 & 4.4 \\
\hline Maryland & 1795 & 72 & 0 & 72 & 4.0 & 4.0 \\
\hline Nebraska & 1426 & 57 & 0 & 57 & 4.0 & 4.0 \\
\hline United States & 221909 & 8241 & 79 & 8162 & 3.7 & 3.7 \\
\hline Hawaii & 505 & 18 & 0 & 18 & 3.6 & 3.6 \\
\hline Utah & 2459 & 89 & 2 & 87 & 3.6 & 3.5 \\
\hline Kansas & 2488 & 81 & $\mathbf{0}$ & 81 & 3.3 & 3.3 \\
\hline California & 9555 & 301 & 4 & 297 & 3.2 & 3.1 \\
\hline Missouri & 4907 & 155 & 3 & 152 & 3.2 & 3.1 \\
\hline South Carolina & 3535 & 109 & 0 & 109 & 3.1 & 3.1 \\
\hline Georgia & 5506 & 169 & 4 & 165 & 3.1 & 3.0 \\
\hline Virginia & 7159 & 206 & 1 & 205 & 2.9 & 2.9 \\
\hline Ohio & 3494 & 102 & 0 & 102 & 2.9 & 2.9 \\
\hline South Dakota & 1353 & 38 & 0 & 38 & 2.8 & 2.8 \\
\hline Colorado & 5350 & 146 & 0 & 146 & 2.7 & 2.7 \\
\hline New Mexico & 2065 & 55 & 0 & 55 & 2.7 & 2.7 \\
\hline Oregon & 11587 & 280 & 0 & 280 & 2.4 & 2.4 \\
\hline North Carolina & 9129 & 195 & 4 & 191 & 2.1 & 2.1 \\
\hline Wyoming & 5273 & 112 & 0 & 112 & 2.1 & 2.1 \\
\hline Louisiana & 4162 & 90 & 2 & 88 & 2.2 & 2.1 \\
\hline Indiana & 3466 & 74 & 3 & 71 & 2.1 & 2.0 \\
\hline Nevada & 2032 & 41 & 2 & 39 & 2.0 & 1.9 \\
\hline Arkansas & 4676 & 85 & 2 & 83 & 1.8 & 1.8 \\
\hline Arizona & 2267 & 42 & 1 & 41 & 1.9 & 1.8 \\
\hline Montana & 9011 & 149 & 0 & 149 & 1.7 & 1.7 \\
\hline Idaho & 8941 & 136 & 0 & 136 & 1.5 & 1.5 \\
\hline Mississippi & 4643 & 69 & 1 & 68 & 1.5 & 1.5 \\
\hline Texas & 11260 & 164 & 4 & 160 & 1.5 & 1.4 \\
\hline Tennessee & 9224 & 114 & 4 & 110 & 1.2 & 1.2 \\
\hline Alabama & 6506 & 81 & 2 & 79 & 1.2 & 1.2 \\
\hline Oklahoma & 3073 & 38 & 0 & 38 & 1.2 & 1.2 \\
\hline
\end{tabular}




\begin{tabular}{|c|c|c|c|c|c|c|}
\hline State & $\begin{array}{c}\text { all } \\
\text { streams }\end{array}$ & $\begin{array}{c}\text { all } \\
\text { cases }\end{array}$ & $\begin{array}{c}\text { not } \\
\text { genr }\end{array}$ & $\underset{\text { genr }}{\text { as }}$ & all & $\begin{array}{l}\text { genr } \\
\%\end{array}$ \\
\hline \multicolumn{7}{|l|}{ (RIVER, cont.) } \\
\hline West Virginia & 8468 & 92 & 7 & 85 & 1.1 & 1.0 \\
\hline Kentucky & 11247 & 91 & 4 & 87 & 0.8 & 0.8 \\
\hline Pennsylvania & 6691 & 55 & 1 & 54 & 0.8 & 0.8 \\
\hline
\end{tabular}

FORK

$\begin{array}{lrrrrrr}\text { West Virginia } & 8468 & 1564 & 429 & 1135 & 18.5 & 13.4 \\ \text { Kentucky } & 11247 & 1921 & 537 & 1384 & 17.1 & 12.3 \\ \text { Utah } & 2366 & 542 & 364 & 178 & 22.9 & 7.5 \\ \text { Ohio } & 3494 & 312 & 137 & 175 & 8.9 & 5.0 \\ \text { Virginia } & 7159 & 423 & 215 & 208 & 5.9 & 2.9 \\ \text { Missouri } & 4907 & 328 & 204 & 124 & 6.7 & 2.5 \\ \text { United States } & 221667 & 14546 & 10160 & 4386 & 6.6 & 2.0 \\ \text { Tennessee } & 9224 & 539 & 355 & 184 & 5.8 & 2.0 \\ \text { North Carolina } & 9129 & 383 & 208 & 175 & 4.2 & 1.9 \\ \text { Illinois } & 2560 & 139 & 90 & 49 & 5.4 & 1.9 \\ \text { Indiana } & 3466 & 176 & 113 & 63 & 5.1 & 1.8 \\ \text { Arkansas } & 4676 & 182 & 104 & 78 & 3.9 & 1.7 \\ \text { Wyoming } & 5271 & 653 & 581 & 72 & 12.4 & 1.4 \\ \text { Pennsylvania } & 6691 & 166 & 101 & 65 & 2.5 & 1.0 \\ \text { Idaho } & 8941 & 968 & 893 & 75 & 10.8 & 0.8 \\ \text { Colorado } & 5350 & 501 & 466 & 35 & 9.4 & 0.7 \\ \text { South Carolina } & 3535 & 59 & 34 & 25 & 1.7 & 0.7 \\ \text { Montana } & 8995 & 1263 & 1211 & 52 & 14.0 & 0.6 \\ \text { California } & 9555 & 867 & 806 & 61 & 9.1 & 0.6 \\ \text { Alaska } & 8526 & 359 & 307 & 52 & 4.2 & 0.6 \\ \text { Oregon } & 11587 & 941 & 895 & 46 & 8.1 & 0.4 \\ \text { New Mexico } & 2065 & 108 & 100 & 8 & 5.2 & 0.4 \\ \text { Oklahoma } & 3073 & 83 & 71 & 12 & 2.7 & 0.4 \\ \text { Louisiana } & 4162 & 69 & 53 & 16 & 1.7 & 0.4 \\ \text { Washington } & 5959 & 565 & 546 & 19 & 9.5 & 0.3 \\ \text { Georgia } & 5506 & 89 & 74 & 15 & 1.6 & 0.3 \\ \text { Arizona } & 2267 & 78 & 72 & 6 & 3.4 & 0.3 \\ \text { South Dakota } & 1347 & 75 & 71 & 4 & 5.6 & 0.3 \\ \text { Texas } & 11259 & 357 & 331 & 26 & 3.2 & 0.2 \\ \text { Alabama } & 6506 & 105 & 92 & 13 & 1.6 & 0.2 \\ \text { Kansas } & 2488 & 97 & 91 & 6 & 3.9 & 0.2 \\ \text { Mississippi } & 4556 & 47 & 40 & 7 & 1.0 & 0.2 \\ \text { Maryland } & 1795 & 19 & 16 & 3 & 1.1 & 0.2 \\ \text { Wisconsin } & 2965 & 84 & 81 & 3 & 2.8 & 0.1 \\ \text { lowa } & 1962 & 58 & 56 & 2 & 3.0 & 0.1 \\ \text { Nebraska } & 1426 & 56 & 54 & 2 & 3.9 & 0.1 \\ \text { Maine } & 3935 & 15 & 13 & 2 & 0.4 & 0.1 \\ \text { New Jersey } & 1345 & 14 & 12 & 2 & 1.0 & 0.1 \\ \text { Connecticut } & 1468 & 2 & 1 & 1 & 0.1 & 0.1 \\ \text { Nevada } & 2028 & 192 & 191 & 1 & 9.5 & 0.0 \\ \text { Minnesota } & 1907 & 53 & 53 & 0 & 2.8 & 0.0 \\ \text { Florida } & 2936 & 32 & 31 & 1 & 1.1 & 0.0 \\ \text { North Dakota } & 622 & 23 & 23 & 0 & 3.7 & 0.0 \\ \text { Michigan } & 4346 & 10 & 9 & 1 & 0.2 & 0.0\end{array}$




\begin{tabular}{|c|c|c|c|c|c|c|}
\hline State & $\begin{array}{c}\text { all } \\
\text { streams }\end{array}$ & $\begin{array}{c}\text { all } \\
\text { cases }\end{array}$ & $\begin{array}{l}\text { not } \\
\text { genr }\end{array}$ & $\begin{array}{c}\text { as } \\
\text { genr }\end{array}$ & $\begin{array}{l}\text { all } \\
\%\end{array}$ & $\begin{array}{c}\text { genr } \\
\%\end{array}$ \\
\hline \multicolumn{7}{|l|}{ (FORK, cont.) } \\
\hline New York & 4382 & 9 & 9 & 0 & 0.2 & 0.0 \\
\hline Vermont & 1263 & 6 & 6 & $\mathbf{0}$ & 0.5 & 0.0 \\
\hline New Hampshire & 1684 & 5 & 5 & 0 & 0.3 & 0.0 \\
\hline Hawaii & 505 & 4 & 4 & 0 & 0.8 & 0.0 \\
\hline Delaware & 433 & 4 & 4 & $\mathbf{0}$ & 0.9 & 0.0 \\
\hline Massachusetts & 2057 & 1 & 1 & 0 & 0.0 & 0.0 \\
\hline \multicolumn{7}{|l|}{ BAYOU } \\
\hline Louisiana & 4162 & 1642 & 0 & 1642 & 39.5 & 39.5 \\
\hline Mississippi & 4556 & 422 & 1 & 421 & 9.3 & 9.2 \\
\hline Arkansas & 4676 & 257 & 1 & 256 & 5.5 & 5.5 \\
\hline Texas & 11259 & 247 & 1 & 246 & 2.2 & 2.2 \\
\hline Florida & 2936 & 54 & 3 & 51 & 1.8 & 1.7 \\
\hline United States & 221660 & 2714 & 13 & 2701 & 1.2 & 1.2 \\
\hline Alabama & 6506 & 34 & 0 & 34 & 0.5 & 0.5 \\
\hline Missouri & 4900 & 14 & 0 & 14 & 0.3 & 0.3 \\
\hline Oklahoma & 3073 & 7 & 0 & 7 & 0.2 & 0.2 \\
\hline Illinois & 2560 & 7 & 1 & 6 & 0.3 & 0.2 \\
\hline Tennessee & 9224 & 10 & 0 & 10 & 0.1 & 0.1 \\
\hline Indiana & 3466 & 6 & 2 & 4 & 0.2 & 0.1 \\
\hline Michigan & 4346 & 4 & 0 & 4 & 0.1 & 0.1 \\
\hline Kentucky & 11247 & 7 & 4 & 3 & 0.1 & 0.0 \\
\hline Ohio & 3494 & 1 & 0 & 1 & 0.0 & 0.0 \\
\hline Montana & 8995 & 1 & 0 & 1 & 0.0 & 0.0 \\
\hline California & 9555 & 1 & 0 & 1 & 0.0 & 0.0 \\
\hline \multicolumn{7}{|l|}{ WASH } \\
\hline Arizona & 2267 & 1082 & 1 & 1081 & 47.7 & 47.7 \\
\hline Nevada & 2032 & 287 & 2 & 285 & 14.1 & 14.0 \\
\hline New Mexico & 2065 & 141 & $\mathbf{0}$ & 141 & 6.8 & 6.8 \\
\hline California & 9555 & 263 & 2 & 261 & 2.8 & 2.7 \\
\hline Colorado & 5350 & 57 & 0 & 57 & 1.1 & 1.1 \\
\hline North Dakota & 626 & 7 & 0 & 7 & 1.1 & 1.1 \\
\hline United States & 221909 & 1910 & 53 & 1857 & 0.9 & 0.8 \\
\hline Utah & 2459 & 18 & 1 & 17 & 0.7 & 0.7 \\
\hline Wyoming & 5273 & 4 & 0 & 4 & 0.1 & 0.1 \\
\hline Idaho & 8941 & 6 & 4 & 2 & 0.1 & 0.0 \\
\hline West Virginia & 8468 & 5 & 5 & 0 & 0.1 & 0.0 \\
\hline Florida & 2936 & 4 & 4 & 0 & 0.1 & 0.0 \\
\hline Alabama & 6506 & 4 & 4 & 0 & 0.1 & 0.0 \\
\hline Texas & 11260 & 4 & 3 & 1 & 0.0 & 0.0 \\
\hline North Carolina & 9129 & 3 & 3 & 0 & 0.0 & 0.0 \\
\hline Kentucky & 11247 & 3 & 3 & 0 & 0.0 & 0.0 \\
\hline Pennsylvania & 6691 & 3 & 3 & 0 & 0.0 & 0.0 \\
\hline Georgia & 5506 & 2 & 2 & 0 & 0.0 & 0.0 \\
\hline Washington & 5959 & 2 & 2 & 0 & 0.0 & 0.0 \\
\hline South Carolina & 3535 & 2 & 2 & 0 & 0.1 & 0.0 \\
\hline Oregon & 11587 & 2 & 1 & 1 & 0.0 & 0.0 \\
\hline Massachusetts & 2057 & 1 & 1 & 0 & 0.0 & 0.0 \\
\hline Michigan & 4371 & 1 & 1 & 0 & 0.0 & 0.0 \\
\hline Louisiana & 4162 & 1 & 1 & 0 & 0.0 & 0.0 \\
\hline
\end{tabular}




$\begin{array}{ccccccc} & \text { all } & \text { all } & \text { not } & \text { as } & \text { all } & \text { genr } \\ \text { State } & \text { streams } & \text { cases } & \text { genr } & \text { genr } & \% & \%\end{array}$

(WASH, cont.)

Mississippi

Alaska

4643

Connecticut

8526

Illinois

1468

Indiana

Missouri

Virginia

Tennessee

2560

3466

4907

7159

9224

\section{SLOUGH}

\begin{tabular}{lr} 
Arkansas & 4676 \\
Illinois & 2560 \\
Alaska & 8526 \\
Florida & 2936 \\
California & 955 \\
Louisiana & 4162 \\
Iowa & 1962 \\
Washington & 5959 \\
Oregon & 11587 \\
Nevada & 2032 \\
North Dakota & 626 \\
Texas & 11260 \\
Nebraska & 1426 \\
Missouri & 4907 \\
United States & 221909 \\
Utah & 2459 \\
Wisconsin & 2965 \\
Mississippi & 4643 \\
Minnesota & 1911 \\
Tennessee & 9224 \\
Alabama & 6506 \\
Idaho & 8941 \\
Montana & 9011 \\
Wyoming & 5273 \\
South Dakota & 1353 \\
Kentucky & 11247 \\
Georgia & 5506 \\
Indiana & 3466 \\
Kansas & 2488 \\
Colorado & 5350 \\
Michigan & 4371 \\
Oklahoma & 3073 \\
North Carolina & 9129 \\
South Carolina & 3535 \\
Maryland & 1795 \\
New Jersey & 1345 \\
West Virginia & 8468 \\
Virginia & 7159 \\
Arizona & 2267 \\
\hline
\end{tabular}

$\begin{array}{rrrrr}157 & 1 & 156 & 3.4 & 3.3 \\ 83 & 0 & 83 & 3.2 & 3.2 \\ 195 & 0 & 195 & 2.3 & 2.3 \\ 68 & 1 & 67 & 2.3 & 2.3 \\ 184 & 0 & 184 & 1.9 & 1.9 \\ 74 & 0 & 74 & 1.8 & 1.8 \\ 39 & 4 & 35 & 2.0 & 1.8 \\ 106 & 2 & 104 & 1.8 & 1.7 \\ 188 & 1 & 187 & 1.6 & 1.6 \\ 29 & 1 & 28 & 1.4 & 1.4 \\ 9 & 1 & 8 & 1.4 & 1.3 \\ 139 & 3 & 136 & 1.2 & 1.2 \\ 18 & 1 & 17 & 1.3 & 1.2 \\ 52 & 4 & 48 & 1.1 & 1.0 \\ 1716 & 41 & 1675 & 0.8 & 0.8 \\ 20 & 0 & 20 & 0.8 & 0.8 \\ 21 & 1 & 20 & 0.7 & 0.7 \\ 30 & 1 & 29 & 0.6 & 0.6 \\ 12 & 0 & 12 & 0.6 & 0.6 \\ 43 & 0 & 43 & 0.5 & 0.5 \\ 31 & 1 & 30 & 0.5 & 0.5 \\ 39 & 1 & 38 & 0.4 & 0.4 \\ 36 & 4 & 32 & 0.4 & 0.4 \\ 20 & 1 & 19 & 0.4 & 0.4 \\ 5 & 0 & 5 & 0.4 & 0.4 \\ 34 & 2 & 32 & 0.3 & 0.3 \\ 18 & 1 & 17 & 0.3 & 0.3 \\ 14 & 2 & 12 & 0.4 & 0.3 \\ 12 & 4 & 8 & 0.5 & 0.3 \\ 11 & 1 & 10 & 0.2 & 0.2 \\ 8 & 0 & 8 & 0.2 & 0.2 \\ 8 & 1 & 7 & 0.3 & 0.2 \\ 5 & 0 & 5 & 0.1 & 0.1 \\ 3 & 0 & 3 & 0.1 & 0.1 \\ 1 & 0 & 1 & 0.1 & 0.1 \\ 1 & 1 & 0 & 0.1 & 0.0 \\ 1 & 0 & 1 & 0.0 & 0.0 \\ 1 & 1 & 0 & 0.0 & 0.0 \\ 1 & 0 & 1 & 0.0 & 0.0\end{array}$




\begin{tabular}{|c|c|c|c|c|c|c|}
\hline State & $\begin{array}{c}\text { all } \\
\text { streams }\end{array}$ & $\begin{array}{l}\text { all } \\
\text { cases }\end{array}$ & $\begin{array}{l}\text { not } \\
\text { genr }\end{array}$ & $\underset{\text { genr }}{\text { as }}$ & $\underset{\%}{\text { all }}$ & $\underset{\%}{\operatorname{genr}}$ \\
\hline \multicolumn{7}{|l|}{ STREAM } \\
\hline Hawaii & 505 & 481 & 0 & 481 & 95.2 & 95.2 \\
\hline Maine & 3935 & 538 & 1 & 537 & 13.7 & 13.6 \\
\hline Dist. Columbia & 19 & 1 & 0 & 1 & 5.3 & 5.3 \\
\hline New Hampshire & 1684 & 26 & 0 & 26 & 1.5 & 1.5 \\
\hline Vermont & 1263 & 14 & 1 & 13 & 1.1 & 1.0 \\
\hline New York & 4382 & 41 & 0 & 41 & 0.9 & 0.9 \\
\hline New Jersey & 1345 & 8 & $\mathbf{0}$ & 8 & 0.6 & 0.6 \\
\hline United States & 221909 & 1206 & 6 & 1200 & 0.5 & 0.5 \\
\hline Connecticut & 1468 & 6 & 0 & 6 & 0.4 & 0.4 \\
\hline Massachusetts & 2057 & 8 & 1 & 7 & 0.4 & 0.3 \\
\hline Minnesota & 1911 & 6 & 0 & 6 & 0.3 & 0.3 \\
\hline Alaska & 8526 & 14 & 0 & 14 & 0.2 & 0.2 \\
\hline Washington & 5959 & 9 & $\mathbf{0}$ & 9 & 0.2 & 0.2 \\
\hline Indiana & 3466 & 6 & $\mathbf{0}$ & 6 & 0.2 & 0.2 \\
\hline Delaware & 433 & 1 & $\mathbf{0}$ & 1 & 0.2 & 0.2 \\
\hline Virginia & 7159 & 10 & 0 & 10 & 0.1 & 0.1 \\
\hline Pennsylvania & 6691 & 8 & 0 & 8 & 0.1 & 0.1 \\
\hline California & 9555 & 7 & 0 & 7 & 0.1 & 0.1 \\
\hline Michigan & 4371 & 5 & 1 & 4 & 0.1 & 0.1 \\
\hline Arizona & 2267 & 3 & 0 & 3 & 0.1 & 0.1 \\
\hline Utah & 2459 & 3 & 0 & 3 & 0.1 & 0.1 \\
\hline South Carolina & 3535 & 2 & $\mathbf{0}$ & 2 & 0.1 & 0.1 \\
\hline Kentucky & 11247 & 2 & 1 & 1 & 0.0 & 0.0 \\
\hline North Carolina & 9129 & 2 & 0 & 2 & 0.0 & 0.0 \\
\hline Montana & 9011 & 2 & 0 & 2 & 0.0 & 0.0 \\
\hline Maryland & 1795 & 1 & 1 & 0 & 0.1 & 0.0 \\
\hline Georgia & 5506 & 1 & 0 & 1 & 0.0 & 0.0 \\
\hline West Virginia & 8468 & 1 & 0 & 1 & 0.0 & 0.0 \\
\hline \multicolumn{7}{|l|}{ DRAIN } \\
\hline Michigan & 4346 & 733 & 3 & 730 & 16.9 & 16.8 \\
\hline Indiana & 3466 & 72 & 0 & 72 & 2.1 & 2.1 \\
\hline Arizona & 2267 & 15 & 0 & 15 & 0.7 & 0.7 \\
\hline Nebraska & 1426 & 10 & $\mathbf{0}$ & 10 & 0.7 & 0.7 \\
\hline Delaware & 433 & 3 & 1 & 2 & 0.7 & 0.5 \\
\hline United States & 221667 & 935 & 12 & 923 & 0.4 & 0.4 \\
\hline Florida & 2936 & 10 & 0 & 10 & 0.3 & 0.3 \\
\hline Iowa & 1962 & 5 & 0 & 5 & 0.3 & 0.3 \\
\hline Idaho & 8941 & 21 & 0 & 21 & 0.2 & 0.2 \\
\hline West Virginia & 8468 & 10 & 0 & 10 & 0.1 & 0.1 \\
\hline Georgia & 5506 & 5 & 0 & 5 & 0.1 & 0.1 \\
\hline Virginia & 7159 & 5 & 0 & 5 & 0.1 & 0.1 \\
\hline Wyoming & 5271 & 4 & $\mathbf{0}$ & 4 & 0.1 & 0.1 \\
\hline South Carolina & 3535 & 4 & 0 & 4 & 0.1 & 0.1 \\
\hline Illinois & 2560 & 2 & 0 & 2 & 0.1 & 0.1 \\
\hline Wisconsin & 2965 & 2 & 0 & 2 & 0.1 & 0.1 \\
\hline South Dakota & 1347 & 2 & 0 & 2 & 0.1 & 0.1 \\
\hline Maryland & 1795 & 2 & 0 & 2 & 0.1 & 0.1 \\
\hline New Jersey & 1345 & 1 & 0 & 1 & 0.1 & 0.1 \\
\hline California & 9555 & 4 & 1 & 3 & 0.0 & 0.0 \\
\hline Oregon & 11587 & 3 & 1 & 2 & 0.0 & 0.0 \\
\hline
\end{tabular}




$\begin{array}{lrrrrrr}\begin{array}{lrrrr}\text { State } \\ \text { (DRAIN, cont.) }\end{array} & \begin{array}{c}\text { all } \\ \text { streams }\end{array} & \begin{array}{c}\text { all } \\ \text { cases }\end{array} & \begin{array}{c}\text { not } \\ \text { genr }\end{array} & \begin{array}{c}\text { as } \\ \text { genr }\end{array} & \begin{array}{c}\text { all } \\ \%\end{array} & \begin{array}{c}\text { genr } \\ \%\end{array} \\ \text { Texas } & 11259 & 3 & 2 & 1 & 0.0 & 0.0 \\ \text { North Carolina } & 9129 & 3 & 0 & 3 & 0.0 & 0.0 \\ \text { Utah } & 2366 & 2 & 1 & 1 & 0.1 & 0.0 \\ \text { Louisiana } & 4162 & 2 & 1 & 1 & 0.0 & 0.0 \\ \text { Montana } & 8995 & 2 & 2 & 0 & 0.0 & 0.0 \\ \text { Arkansas } & 4676 & 2 & 0 & 2 & 0.0 & 0.0 \\ \text { New York } & 4382 & 2 & 0 & 2 & 0.0 & 0.0 \\ \text { Massachusetts } & 2057 & 1 & 0 & 1 & 0.0 & 0.0 \\ \text { Kentucky } & 11247 & 1 & 0 & 1 & 0.0 & 0.0 \\ \text { Mississippi } & 4556 & 1 & 0 & 1 & 0.0 & 0.0 \\ \text { New Mexico } & 2065 & 1 & 0 & 1 & 0.0 & 0.0 \\ \text { Ohio } & 3494 & 1 & 0 & 1 & 0.0 & 0.0 \\ \text { Washington } & 5959 & 1 & 0 & 1 & 0.0 & 0.0 \\ \text { ARROYO } & & & & & & \\ \text { New Mexico } & 2065 & 499 & 0 & 499 & 24.2 & 24.2 \\ \text { Colorado } & 5350 & 119 & 1 & 118 & 2.2 & 2.2 \\ \text { California } & 9555 & 111 & 1 & 110 & 1.2 & 1.2 \\ \text { United States } & 221909 & 750 & 5 & 745 & 0.3 & 0.3 \\ \text { Texas } & 11260 & 15 & 1 & 14 & 0.1 & 0.1 \\ \text { Arizona } & 2267 & 2 & 0 & 2 & 0.1 & 0.1 \\ \text { Montana } & 9011 & 2 & 1 & 1 & 0.0 & 0.0 \\ \text { Kansas } & 2488 & 2 & 1 & 1 & 0.1 & 0.0 \\ & & & & & & \end{array}$

\section{SWAMP}

$\begin{array}{lrrrrrr}\text { South Carolina } & 3535 & 185 & 17 & 168 & 5.2 & 4.8 \\ \text { North Carolina } & 9129 & 349 & 30 & 319 & 3.8 & 3.5 \\ \text { Virginia } & 7159 & 234 & 12 & 22 & 3.3 & 3.1 \\ \text { United States } & 221909 & 1087 & 358 & 729 & 0.5 & 0.3 \\ \text { Hawaii } & 505 & 1 & 0 & 1 & 0.2 & 0.2 \\ \text { New Jersey } & 1345 & 23 & 21 & 2 & 1.7 & 0.1 \\ \text { Georgia } & 5506 & 18 & 10 & 8 & 0.3 & 0.1 \\ \text { Maryland } & 1795 & 10 & 8 & 2 & 0.6 & 0.1 \\ \text { Florida } & 2936 & 7 & 5 & 2 & 0.2 & 0.1 \\ \text { Nebraska } & 1426 & 2 & 0 & 2 & 0.1 & 0.1 \\ \text { Oregon } & 11587 & 38 & 38 & 0 & 0.3 & 0.0 \\ \text { Montana } & 9011 & 34 & 34 & 0 & 0.4 & 0.0 \\ \text { Connecticut } & 1468 & 25 & 25 & 0 & 1.7 & 0.0 \\ \text { Pennsylvania } & 6691 & 22 & 22 & 0 & 0.3 & 0.0 \\ \text { Massachusetts } & 2057 & 18 & 18 & 0 & 0.9 & 0.0 \\ \text { Alabama } & 6506 & 13 & 11 & 2 & 0.2 & 0.0 \\ \text { Washington } & 5959 & 11 & 11 & 0 & 0.2 & 0.0 \\ \text { Idaho } & 8941 & 10 & 10 & 0 & 0.1 & 0.0 \\ \text { New York } & 4382 & 10 & 10 & 0 & 0.2 & 0.0 \\ \text { West Virginia } & 8468 & 9 & 9 & 0 & 0.1 & 0.0 \\ \text { Maine } & 3935 & 7 & 7 & 0 & 0.2 & 0.0 \\ \text { Rhode Island } & 254 & 6 & 6 & 0 & 2.4 & 0.0 \\ \text { California } & 9555 & 6 & 6 & 0 & 0.1 & 0.0 \\ \text { Wisconsin } & 2965 & 5 & 5 & 0 & 0.2 & 0.0 \\ \text { Kentucky } & 11247 & 5 & 5 & 0 & 0.0 & 0.0\end{array}$


$\begin{array}{ccccccc} & \text { all } & \text { all } & \text { not } & \text { as } & \text { all } & \text { genr } \\ \text { State } & \text { streams } & \text { cases } & \text { genr } & \text { genr } & \% & \%\end{array}$

(SWAMP, cont.)

$\begin{array}{lr}\text { Mississippi } & 4643 \\ \text { Minnesota } & 1911 \\ \text { Michigan } & 4371 \\ \text { Ohio } & 3494 \\ \text { New Hampshire } & 1684 \\ \text { Tennessee } & 9224 \\ \text { Indiana } & 3466 \\ \text { Alaska } & 8526 \\ \text { Delaware } & 433 \\ \text { Colorado } & 5350 \\ \text { Arizona } & 2267 \\ \text { North Dakota } & 626 \\ \text { Louisiana } & 4162 \\ \text { Missouri } & 4907 \\ \text { Wyoming } & 5273 \\ \text { Texas } & 11260\end{array}$

$\begin{array}{lllll}4 & 4 & 0 & 0.1 & 0.0 \\ 4 & 4 & 0 & 0.2 & 0.0 \\ 4 & 4 & 0 & 0.1 & 0.0 \\ 4 & 3 & 1 & 0.1 & 0.0 \\ 3 & 3 & 0 & 0.2 & 0.0 \\ 3 & 3 & 0 & 0.0 & 0.0 \\ 3 & 3 & 0 & 0.1 & 0.0 \\ 3 & 3 & 0 & 0.0 & 0.0 \\ 3 & 3 & 0 & 0.7 & 0.0 \\ 2 & 2 & 0 & 0.0 & 0.0 \\ 1 & 1 & 0 & 0.0 & 0.0 \\ 1 & 1 & 0 & 0.2 & 0.0 \\ 1 & 1 & 0 & 0.0 & 0.0 \\ 1 & 1 & 0 & 0.0 & 0.0 \\ 1 & 1 & 0 & 0.0 & 0.0 \\ 1 & 1 & 0 & 0.0 & 0.0\end{array}$

\section{CANADA}

$\begin{array}{lr}\text { New Mexico } & 2065 \\ \text { United States } & 221909 \\ \text { California } & 9555 \\ \text { New York } & 4382 \\ \text { Pennsylvania } & 6691 \\ \text { Michigan } & 4371 \\ \text { Colorado } & 5350 \\ \text { Montana } & 9011 \\ \text { Virginia } & 7159 \\ \text { Oregon } & 11587 \\ \text { Nebraska } & 1426 \\ \text { Arkansas } & 4676 \\ \text { Ohio } & 3494 \\ \text { Georgia } & 5506 \\ \text { Texas } & 11260\end{array}$

$\begin{array}{rrrrr}236 & 0 & 236 & 11.4 & 11.4 \\ 265 & 18 & 247 & 0.1 & 0.1 \\ 9 & 0 & 9 & 0.1 & 0.1 \\ 5 & 5 & 0 & 0.1 & 0.0 \\ 4 & 4 & 0 & 0.1 & 0.0 \\ 2 & 2 & 0 & 0.0 & 0.0 \\ 1 & 0 & 1 & 0.0 & 0.0 \\ 1 & 1 & 0 & 0.0 & 0.0 \\ 1 & 1 & 0 & 0.0 & 0.0 \\ 1 & 1 & 0 & 0.0 & 0.0 \\ 1 & 1 & 0 & 0.1 & 0.0 \\ 1 & 1 & 0 & 0.0 & 0.0 \\ 1 & 1 & 0 & 0.0 & 0.0 \\ 1 & 1 & 0 & 0.0 & 0.0 \\ 1 & 0 & 1 & 0.0 & 0.0\end{array}$

\section{PRONG}

$\begin{array}{lrrrrrr}\text { Delaware } & 433 & 22 & 0 & 22 & 5.1 & 5.1 \\ \text { Tennessee } & 9224 & 96 & 59 & 37 & 1.0 & 0.4 \\ \text { North Carolina } & 9129 & 137 & 109 & 28 & 1.5 & 0.3 \\ \text { Wyoming } & 5273 & 71 & 53 & 18 & 1.3 & 0.3 \\ \text { Louisiana } & 4162 & 32 & 21 & 11 & 0.8 & 0.3 \\ \text { Mississippi } & 4643 & 27 & 15 & 12 & 0.6 & 0.3 \\ \text { Maryland } & 1795 & 13 & 8 & 5 & 0.7 & 0.3 \\ \text { Arkansas } & 4676 & 36 & 26 & 10 & 0.8 & 0.2 \\ \text { United States } & 221909 & 792 & 577 & 215 & 0.4 & 0.1 \\ \text { Texas } & 11260 & 82 & 73 & 9 & 0.7 & 0.1 \\ \text { Georgia } & 5506 & 32 & 26 & 6 & 0.6 & 0.1 \\ \text { Missouri } & 4907 & 32 & 29 & 3 & 0.7 & 0.1 \\ \text { Virginia } & 7159 & 26 & 16 & 10 & 0.4 & 0.1 \\ \text { Kentucky } & 11247 & 25 & 19 & 6 & 0.2 & 0.1 \\ \text { Alabama } & 6506 & 24 & 20 & 4 & 0.4 & 0.1 \\ \text { Florida } & 2936 & 24 & 21 & 3 & 0.8 & 0.1\end{array}$


Stream Generic Terms 363

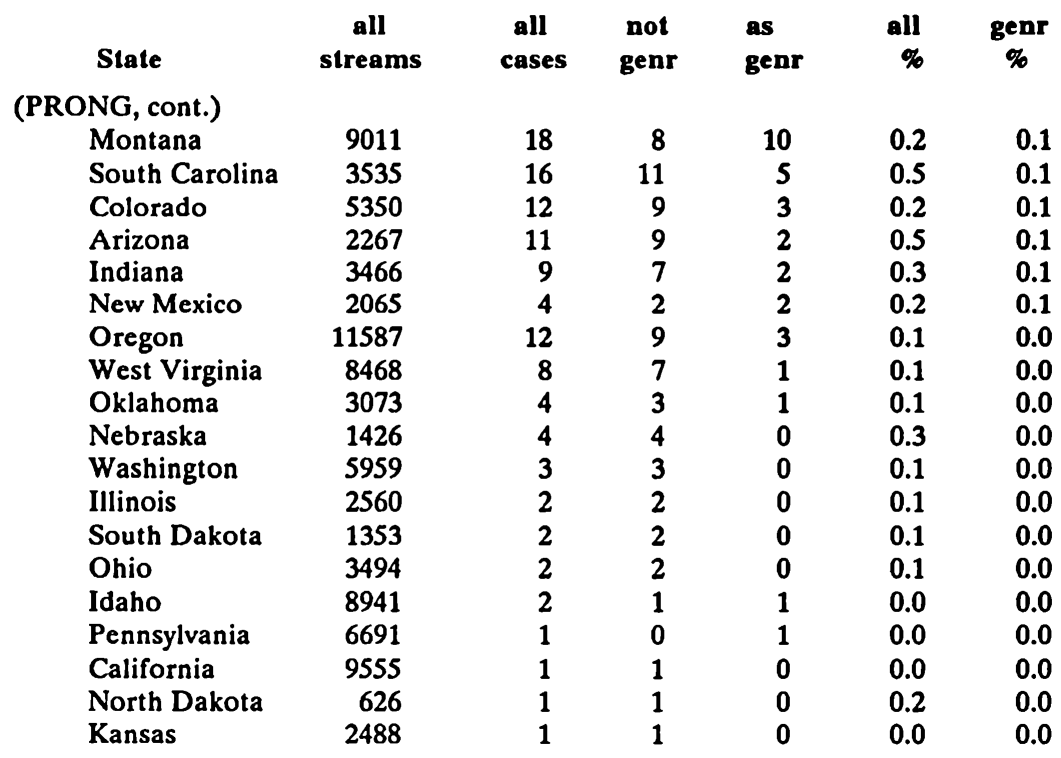

LICK

$\begin{array}{lrrrrrr}\text { Kentucky } & 11247 & 440 & 362 & 78 & 3.9 & 0.7 \\ \text { West Virginia } & 8468 & 273 & 237 & 36 & 3.2 & 0.4 \\ \text { Ohio } & 3494 & 53 & 39 & 14 & 1.5 & 0.4 \\ \text { Virginia } & 7159 & 115 & 96 & 19 & 1.6 & 0.3 \\ \text { United States } & 221909 & 1511 & 1350 & 161 & 0.7 & 0.1 \\ \text { Pennsylvania } & 6691 & 94 & 90 & 4 & 1.4 & 0.1 \\ \text { Indiana } & 3466 & 52 & 49 & 3 & 1.5 & 0.1 \\ \text { Illinois } & 2560 & 26 & 24 & 2 & 1.0 & 0.1 \\ \text { Maryland } & 1795 & 8 & 7 & 1 & 0.4 & 0.1 \\ \text { Tennessee } & 9224 & 98 & 97 & 1 & 1.1 & 0.0 \\ \text { Arkansas } & 4676 & 48 & 48 & 0 & 1.0 & 0.0 \\ \text { Missouri } & 4907 & 43 & 43 & 0 & 0.9 & 0.0 \\ \text { Texas } & 11260 & 31 & 31 & 0 & 0.3 & 0.0 \\ \text { North Carolina } & 9129 & 31 & 31 & 0 & 0.3 & 0.0 \\ \text { Alabama } & 6506 & 30 & 30 & 0 & 0.5 & 0.0 \\ \text { Louisiana } & 4162 & 26 & 25 & 1 & 0.6 & 0.0 \\ \text { Oregon } & 11587 & 25 & 23 & 2 & 0.2 & 0.0 \\ \text { Idaho } & 8941 & 16 & 16 & 0 & 0.2 & 0.0 \\ \text { California } & 9555 & 16 & 16 & 0 & 0.2 & 0.0 \\ \text { Mississippi } & 4643 & 16 & 16 & 0 & 0.3 & 0.0 \\ \text { South Carolina } & 3535 & 12 & 12 & 0 & 0.3 & 0.0 \\ \text { Georgia } & 5506 & 11 & 11 & 0 & 0.2 & 0.0 \\ \text { Montana } & 9011 & 11 & 11 & 0 & 0.1 & 0.0 \\ \text { Oklahoma } & 3073 & 8 & 8 & 0 & 0.3 & 0.0 \\ \text { Iowa } & 1962 & 7 & 7 & 0 & 0.4 & 0.0 \\ \text { Colorado } & 5350 & 6 & 6 & 0 & 0.1 & 0.0 \\ \text { Washington } & 5959 & 4 & 4 & 0 & 0.1 & 0.0 \\ \text { New York } & 4382 & 4 & 4 & 0 & 0.1 & 0.0 \\ \text { Wyoming } & 5273 & 3 & 3 & 0 & 0.1 & 0.0\end{array}$




\begin{tabular}{|c|c|c|c|c|c|c|}
\hline State & $\begin{array}{c}\text { all } \\
\text { streams }\end{array}$ & $\begin{array}{c}\text { all } \\
\text { cases }\end{array}$ & $\begin{array}{l}\text { not } \\
\text { genr }\end{array}$ & $\begin{array}{l}\text { as } \\
\text { genr }\end{array}$ & all & $\underset{\%}{\operatorname{genr}}$ \\
\hline \multicolumn{7}{|l|}{ (LICK, cont.) } \\
\hline Vermont & 1263 & 1 & 1 & $\mathbf{0}$ & 0.1 & 0.0 \\
\hline Michigan & 4371 & 1 & 1 & 0 & 0.0 & 0.0 \\
\hline Alaska & 8526 & 1 & 1 & $\mathbf{0}$ & 0.0 & 0.0 \\
\hline Utah & 2459 & 1 & 1 & 0 & 0.0 & 0.0 \\
\hline \multicolumn{7}{|l|}{ KILL } \\
\hline New York & 4382 & 143 & 1 & 142 & 3.3 & 3.2 \\
\hline New Jersey & 1345 & 5 & 1 & 4 & 0.4 & 0.3 \\
\hline Vermont & 1263 & 3 & 1 & 2 & 0.2 & 0.2 \\
\hline United States & 221667 & 169 & 14 & 155 & 0.1 & 0.1 \\
\hline Pennsylvania & 6691 & 5 & 0 & 5 & 0.1 & 0.1 \\
\hline Kansas & 2488 & 3 & 3 & 0 & 0.1 & 0.0 \\
\hline West Virginia & 8468 & 2 & 0 & 2 & 0.0 & 0.0 \\
\hline Arkansas & 4676 & 1 & 1 & 0 & 0.0 & 0.0 \\
\hline California & 9555 & 1 & 1 & $\mathbf{0}$ & 0.0 & 0.0 \\
\hline Michigan & 4346 & 1 & 1 & 0 & 0.0 & 0.0 \\
\hline Kentucky & 11247 & 1 & 1 & $\mathbf{0}$ & 0.0 & 0.0 \\
\hline Nevada & 2028 & 1 & 1 & 0 & 0.0 & 0.0 \\
\hline North Carolina & 9129 & 1 & 1 & $\mathbf{0}$ & 0.0 & 0.0 \\
\hline Indiana & 3466 & 1 & 1 & $\mathbf{0}$ & 0.0 & 0.0 \\
\hline Montana & 8995 & 1 & 1 & 0 & 0.0 & 0.0 \\
\hline
\end{tabular}

\section{DITCH}

$\begin{array}{lrrrrrr}\text { Delaware } & 433 & 53 & 1 & 52 & 12.2 & 12.0 \\ \text { Maryland } & 1795 & 14 & 2 & 12 & 0.8 & 0.7 \\ \text { Indiana } & 3466 & 15 & 2 & 13 & 0.4 & 0.4 \\ \text { New Jersey } & 1345 & 4 & 0 & 4 & 0.3 & 0.3 \\ \text { Florida } & 2936 & 8 & 3 & 5 & 0.3 & 0.2 \\ \text { United States } & 221667 & 200 & 64 & 136 & 0.1 & 0.1 \\ \text { Wyoming } & 5271 & 14 & 8 & 6 & 0.3 & 0.1 \\ \text { Alabama } & 6506 & 11 & 2 & 9 & 0.2 & 0.1 \\ \text { Mississippi } & 4556 & 5 & 1 & 4 & 0.1 & 0.1 \\ \text { Ohio } & 3494 & 3 & 0 & 3 & 0.1 & 0.1 \\ \text { Illinois } & 2560 & 3 & 0 & 3 & 0.1 & 0.1 \\ \text { Connecticut } & 1468 & 1 & 0 & 1 & 0.1 & 0.1 \\ \text { Iowa } & 1962 & 1 & 0 & 1 & 0.1 & 0.1 \\ \text { Minnesota } & 1907 & 1 & 0 & 1 & 0.1 & 0.1 \\ \text { Idaho } & 8941 & 13 & 13 & 0 & 0.1 & 0.0 \\ \text { California } & 9555 & 8 & 6 & 2 & 0.1 & 0.0 \\ \text { Oregon } & 11587 & 7 & 7 & 0 & 0.1 & 0.0 \\ \text { North Carolina } & 9129 & 6 & 3 & 3 & 0.1 & 0.0 \\ \text { Texas } & 11259 & 5 & 0 & 5 & 0.0 & 0.0 \\ \text { Montana } & 8995 & 4 & 2 & 2 & 0.0 & 0.0 \\ \text { Tennessee } & 9224 & 4 & 1 & 3 & 0.0 & 0.0 \\ \text { Georgia } & 5506 & 3 & 1 & 2 & 0.1 & 0.0 \\ \text { Louisiana } & 4162 & 2 & 0 & 2 & 0.0 & 0.0 \\ \text { Pennsylvania } & 6691 & 2 & 2 & 0 & 0.0 & 0.0 \\ \text { Virginia } & 7159 & 2 & 1 & 1 & 0.0 & 0.0 \\ \text { Colorado } & 5350 & 2 & 2 & 0 & 0.0 & 0.0\end{array}$




\begin{tabular}{|c|c|c|c|c|c|c|}
\hline State & $\begin{array}{c}\text { all } \\
\text { streams }\end{array}$ & $\begin{array}{c}\text { all } \\
\text { cases }\end{array}$ & $\begin{array}{c}\text { not } \\
\text { genr }\end{array}$ & $\begin{array}{l}\text { as } \\
\text { genr }\end{array}$ & all & $\underset{\%}{\operatorname{genr}}$ \\
\hline \multicolumn{7}{|l|}{ (DITCH, cont.) } \\
\hline Maine & 3935 & 1 & 1 & 0 & 0.0 & 0.0 \\
\hline Alaska & 8526 & 1 & 1 & 0 & 0.0 & 0.0 \\
\hline Nevada & 2028 & 1 & 1 & $\mathbf{0}$ & 0.0 & 0.0 \\
\hline Kansas & 2488 & 1 & $\mathbf{0}$ & 1 & 0.0 & 0.0 \\
\hline Missouri & 4907 & 1 & 1 & 0 & 0.0 & 0.0 \\
\hline South Dakota & 1347 & 1 & 1 & $\mathbf{0}$ & 0.1 & 0.0 \\
\hline West Virginia & 8468 & 1 & 1 & $\mathbf{0}$ & 0.0 & 0.0 \\
\hline Washington & 5959 & 1 & 0 & 1 & 0.0 & 0.0 \\
\hline South Carolina & 3535 & 1 & 1 & 0 & 0.0 & 0.0 \\
\hline
\end{tabular}

\section{OUTLET}

$\begin{array}{lrr}\text { New York } & 4382 \\ \text { Michigan } & 4371 \\ \text { Wisconsin } & 296 \\ \text { Maine } & 3935 \\ \text { United States } & 221909 \\ \text { Pennsylvania } & 691 \\ \text { Ohio } & 3494 \\ \text { Minnesota } & 1911 \\ \text { Iowa } & 1962 \\ \text { South Dakota } & 1353 \\ \text { Washington } & 5959 \\ \text { Idaho } & 8941 \\ \text { Arizona } & 2267 \\ \text { California } & 9555 \\ \text { Indiana } & 3466 \\ \text { Mississippi } & 4643 \\ \text { Wyoming } & 5273 \\ \text { Montana } & 9011\end{array}$

$\begin{array}{rrrrr}78 & 1 & 77 & 1.8 & 1.8 \\ 15 & 2 & 13 & 0.3 & 0.3 \\ 10 & 1 & 9 & 0.3 & 0.3 \\ 10 & 2 & 8 & 0.3 & 0.2 \\ 143 & 17 & 126 & 0.1 & 0.1 \\ 6 & 0 & 6 & 0.1 & 0.1 \\ 5 & 0 & 5 & 0.1 & 0.1 \\ 3 & 1 & 2 & 0.2 & 0.1 \\ 3 & 1 & 2 & 0.2 & 0.1 \\ 1 & 0 & 1 & 0.1 & 0.1 \\ 4 & 4 & 0 & 0.1 & 0.0 \\ 2 & 1 & 1 & 0.0 & 0.0 \\ 1 & 0 & 1 & 0.0 & 0.0 \\ 1 & 1 & 0 & 0.0 & 0.0 \\ 1 & 1 & 0 & 0.0 & 0.0 \\ 1 & 0 & 1 & 0.0 & 0.0 \\ 1 & 1 & 0 & 0.0 & 0.0 \\ 1 & 1 & 0 & 0.0 & 0.0\end{array}$

\section{COULEE}

$\begin{array}{lrrrrrr}\text { North Dakota } & 626 & 16 & 0 & 16 & 2.6 & 2.6 \\ \text { Louisiana } & 4162 & 59 & 0 & 59 & 1.4 & 1.4 \\ \text { Montana } & 9011 & 28 & 9 & 19 & 0.3 & 0.2 \\ \text { Minnesota } & 1911 & 2 & 1 & 1 & 0.1 & 0.1 \\ \text { United States } & 221909 & 126 & 27 & 99 & 0.1 & 0.0 \\ \text { Washington } & 5959 & 7 & 7 & 0 & 0.1 & 0.0 \\ \text { Wisconsin } & 2965 & 7 & 6 & 1 & 0.2 & 0.0 \\ \text { Alaska } & 8526 & 1 & 0 & 1 & 0.0 & 0.0 \\ \text { Wyoming } & 5273 & 1 & 0 & 1 & 0.0 & 0.0 \\ \text { Iowa } & 1962 & 1 & 1 & 0 & 0.1 & 0.0 \\ \text { Oregon } & 11587 & 1 & 1 & 0 & 0.0 & 0.0 \\ \text { South Dakota } & 1353 & 1 & 1 & 0 & 0.1 & 0.0 \\ \text { Utah } & 2459 & 1 & 1 & 0 & 0.0 & 0.0 \\ \text { Idaho } & 8941 & 1 & 0 & 1 & 0.0 & 0.0\end{array}$




\title{
Geographic Names Information System (GNIS)
}

GNIS, developed by the Branch of Geographic Names, Office of Geographic and Cartographic Research, National Mapping Division, is the basis for Professional Paper 1200-The National Gazetteer of the United States, which is being published as a series of individual state gazetteer volumes. The information contained in GNIS is interactively available at the U.S. Geological Survey's information offices of the National Mapping Division. Special searches of this system may be requested with the results available in bound listings and on magnetic tape.

Geographical names for all of the states have been collected from large scale topographic maps, and lists of these names are available as interim products. This is Phase I of the project. Phase II, including names found in federal, state, and other sources as well as historical material, has been completed for only seven states and is in progress for about sixteen more.

State volumes, representing Phase II, are so far available for New Jersey, Delaware, Kansas, Arizona, Indiana, South Dakota, and North Dakota. Also available is the United States Concise 1990, which lists in one volume the major features in all of the states. These may be ordered from

\author{
U.S. Geological Survey \\ Books and Open-File Reports \\ Federal Center, Bldg. 41 \\ Box 25425 \\ Denver, CO 80225
}

For information on all of these products, contact

Executive Secretary, Domestic Names Committee

U.S. Board on Geographic Names

U.S. Geological Survey

523 National Center

Reston, VA 22092

(703) 648-4544

FTS 8-959-4544 